\title{
Assessment of growth and phytochemical quality of Gynura procumbens through nitrogen, potassium fertilization and evapotranspiration replacement interaction
}

\author{
Mohamad Fhaizal Mohamad Bukhori ${ }^{\mathrm{a}, \mathrm{b}^{*}}$, Hawa ZE Jaafar ${ }^{\mathrm{a}}$, Ali Ghasemzadeh ${ }^{\mathrm{a}}$, Uma Rani Sinniah ${ }^{\mathrm{a}}$, \\ Gayatri Karipayac $^{c}$, Keezrawati Mujan Yusuf ${ }^{\mathrm{d}}$ \\ ${ }^{a}$ Department of Crop Science, Faculty of Agriculture, Universiti Putra Malaysia, Serdang 43400, Selangor, Malaysia \\ ${ }^{b}$ Centre for Pre-University Studies, Universiti Malaysia Sarawak, 94300 Samarahan, Sarawak, Malaysia \\ 'Institute of Biological Sciences, Faculty of Science, Universiti Malaya, 50603 Kuala Lumpur, Malaysia \\ ${ }^{d}$ Faculty of Language and Communication, Universiti Malaysia Sarawak, 94300 Samarahan, Sarawak, Malaysia
}

Received 11th October 2019 / Accepted 18th April 2020

\begin{abstract}
Despite the progressive reports on potential pharmacological properties of G. procumbens, the importance of agronomic requirements to produce high yields and phytochemical content that may vary due to environmental variations are often overlooked. Therefore, this study was conducted to examine the effects of N, K and ER interaction on the growth and phytochemical content of G. procumbens. The study was a three-factorial experiment; two rates of $\mathrm{N}$ and $\mathrm{K}$, four rates of ER and three $\mathrm{H}$ time. The treatments have affected plant growth and phytochemical content significantly $(\mathrm{p} \leq 0.05)$ with stronger effect on physiology and biochemical attributes $(\mathrm{p} \leq 0.01)$. The study has shown discrete effect on growth, physiology, and phytochemicals content with N0K30>N90K0 and ER 75>50>100>25\% treatment. The highest and lowest yield of plant biomass and phytochemical were observed under N0K30(70) and N90K0(25), respectively. The results have shown that the interaction and effect of treatments are highly significant $(\mathrm{p} \leq 0.0001)$ in Cond, CNB, TChlC, TPrC and TFC analysis, $(\mathrm{p} \leq 0.05)$ in NoL, CF and PWP, and not significant in TLA, Photo, TCC, TLC and TPC. The 75\% ER has produced significant output of biomass as well as phytochemical content. The study also showed that low rate of $\mathrm{N}$, moderate rate of $\mathrm{K}$ with $75 \%$ ER have produced high biomass as well as phytochemical content. Meanwhile, caffeic acid and kaempferol were demonstrated as the lead secondary metabolite compounds in this study.
\end{abstract}

Keywords: evapotranspiration, fertilizer, growth, Gynura, physiology, phytochemical

\section{INTRODUCTION}

Many enzymes in photosynthesis and phytochemical (metabolite) processes require nitrogen $(\mathrm{N})$, potassium $(\mathrm{K})$ and water as cofactors (Jimenez-Garcia et al., 2013). Numerous studies have suggested the association between $\mathrm{N}$-, K- and water-dependent enzymes such as nitrate reductase, pyruvate kinase, Rubisco and starch synthase with plant metabolic regulation (Mikkelsen, 2008; Pant et al., 2015; Wu et al., 2011).
Due to the increasing understanding of metabolic processes regulation, $\mathrm{N}, \mathrm{K}$ and water availabilitydependent reaction studies have come into the latter mechanisms (Davies et al., 2009; Espíritosanto et al., 1999; Kaiser et al., 2016; Pal et al., 2015; Smith et al., 1993; Soubeyrand et al., 2014). In order to understand how N, K and water affected phytochemical content quality, studies must evaluate metabolic regulation at various biological

*Author for correspondence: Mohamad Fhaizal Mohamad Bukhori, Department of Crop Science, Faculty of Agriculture, Universiti Putra Malaysia, Serdang 43400, Selangor, Malaysia. Email mbmfhaizal@unimas.my 
stages including photosynthesis, primary and secondary metabolites to identify the target rates of $\mathrm{N}, \mathrm{K}$ and water to verify their individual roles.

In Gynura procumbens ( $G$. procumbens), lead compounds, namely caffeic acid and kaempferol, represent the large secondary metabolites contributed to plant-environmental interactions, particularly in biotic-abiotic stress responses (Altemimi et al., 2017; Noviyanti et al., 2017; Ramawat et al., 2009). Synthesis and accumulation of these compounds and other derivatives, such as ferulic acid and quercetin, in plant tissues are dependent on plant organ, developmental stage and environmental factors (Cheynier et al., 2013; Galieni et al., 2015; Michalak, 2006; Mongkhonsin et al., 2016; Fu et al., 2015). Among the factors, light, temperature, water, $\mathrm{N}$ and $\mathrm{K}$ are the best characterized although the relations involving these factors have proven to be complex. Thus, the present study can adopt a multilevel approach combining previous reports on plant metabolite and cellular respiration with selected rates of $\mathrm{N}, \mathrm{K}$ and water grown under controlled conditions. The resulting comprehensive data set covering various parameters including growth rate, phytochemical content, physiology state and spectroscopic attributes allows the study to present definite hypotheses on the causes, which provide better recommendation for agricultural input.

In plants, water content may affect metabolites composition because water is characterized as a source of energy to synthesize organic compounds during the process of photosynthesis (Yadav et al., 2014). Therefore, water has an important role in plant growth and is essential in determining yield and quality (Dunford \& Vazquez, 2005). Deficit or surplus water content are environmental stresses that can significantly influence growth and productivity (Selmar \& Kleinwächter, 2013). Thus, identifying growth stages and compounds profile will allow water supply regimes to maximize yield and efficiently utilize water resources (Houle et al., 2001). Some studies found that the rates and frequency of water intervals affect plant performance either by reducing growth and yield, growth characters and yield component, increasing dry mass and yield and decreasing carbohydrate content and seed yield (Dunford \& Vazquez, 2005; Khalid, 2006; Mohd Zain et al., 2014a; Mráz et al., 2014). The findings suggest that water treatment, water use efficiency and plant developmental stages influence overall plant performance including growth and metabolic activities. There are several methods to measure water content requirement such as evapotranspiration replacement (ER), water holding capacity and bulk density capacity.

In general, water treatment in plants is depends on the target output, such as biomass yield or phytochemical content, and supplementation of $\mathrm{N}$ and $\mathrm{K}$ (Kleinwächter \& Selmar, 2014). This is because phytochemical content and composition as well as growth and development consistency are susceptible to environmental factors, including water availability and fertilization due to plant heterogeneity (Cheynier et al., 2013b; Figueiredo et al., 2008; Herrmann, 1995; Massad et al., 2011; Netala et al., 2015; Patra et al., 2013). Therefore, it is wise to determine the optimum ER to optimize the productivity of water unit and to determine the effects of fertilizer supply on plant tolerance to drought. For these reasons, this study attempted to analyze the interaction of $\mathrm{N}, \mathrm{K}$ and $\mathrm{ER}$ on growth, physiology, and phytochemical contents of $G$. procumbens at different harvesting time.

\section{MATERIALS AND METHODS}

\section{Experimental design and treatments}

The study was conducted based on Randomized Complete Block Design (RCBD) and the data were processed using Duncan Multiple Range Test (DMRT) and Pearson's Correlation Coefficients (PCC), SAS ${ }^{\circledR} 9.4$ software (Version 8.0, SAS Institute Inc., and Cary, NC, USA.). The study was a three-factorial experiment. The first factor was two rates of $\mathrm{N}$ and $\mathrm{K}$, vir. $0(0.00 \mathrm{~g}$ total per plant) and $90(1.08 \mathrm{~g}) \mathrm{kg} \mathrm{N} / \mathrm{ha}(\mathrm{N} 0$ and N90), applied in the form of urea and $0(0.00 \mathrm{~g})$ and 30 $(0.36 \mathrm{~g}) \mathrm{kg} \mathrm{K} / \mathrm{ha}(\mathrm{K} 0$ and $\mathrm{K} 30)$, applied in the form of Muriate of potash. The second factor was four rates of evapotranspiration replacement (ER), vir. 100 (percent, \% of water replacement of total water lost volume per plant) as a control, 75 (75\%), $50(50 \%)$ and $25(25 \%)$ per plant $(100 \%$ ER, $75 \%$ ER, 50\% ER and 25\% ER), applied manually at alternate days of irrigation frequency. 
The $\mathrm{N}$ and $\mathrm{K}$ were divided into three supply phases (three months). About $33.3 \%$ of total $\mathrm{N}$ and $\mathrm{K}$ applied at the first week of the month in each phase (each month). The third factor was three harvesting $(\mathrm{H})$ time, vir. 4, 8 and 12 weeks after treatment (WAT).

\section{Plant preparation and maintenance}

Gynura procumbens mother plants were obtained from UPM nursery collection. The propagation was conducted using cuttings from mature stem $(10 \mathrm{~cm}, \geq 2$ internode $)$ and placed in seed trays containing uniform mixture of sand: coco-peat $(1: 1 \mathrm{v} / \mathrm{v})$ for rooting purposes (Awang et al., 2009; Treder, 2008). Then, the regenerated plants were transferred into polyethylene bags $(25 \mathrm{~cm}$ diameter) containing uniform mixture of soilless medium (coco-peat: burnt paddy husk: well composted chicken manure $(5: 5: 1 \mathrm{v} / \mathrm{v} / \mathrm{v})$ ratio), and left for acclimatization until they were ready for treatments (Jaafar et al., 2012). The $\mathrm{pH}$ value of the growing media was at 5.5 to 7.0 (Chan et al., 2009). The growth house average temperatures were between 22.9 to $27.2^{\circ} \mathrm{C}$, and the relative humidity was between 50 to $70 \%$. Meanwhile, the average daytime irradiance was at $500 \mu \mathrm{mol} \mathrm{m} \mathrm{s}^{-1}$ photosynthetic active radiation. The plants were watered manually once a day in the morning or when necessary. Non-chemical pest and disease control were conducted manually at the sight of part presence.

\section{Sampling}

Each combined treatment consisted of 72 plants. A total of 216 samples was used in the study. The samples were harvested at 4, 8 and 12 WAT. Three plants per treatment were sampled on each harvesting time.

\section{Total plant dry weight}

The plants were harvested randomly and separately at 4, 8 and 12 WAT. The plants were separated into leaves, stems, and roots manually. Fresh plant materials were weighed and put in labelled paper bags. Next, they were dried at $40^{\circ} \mathrm{C}$ in forced draft oven until constant dry weight (TPDW) was obtained (Oyedeji et al., 2014; Peterson \& Zelitch, 1982). The biomass was measured using electronic weighing machine. The unit of weight used was g. Dried samples were ground to fine powder $(0.25 \mathrm{~mm})$ using grinder and kept at room temperature until analysis.

\section{Number of leaf and total leaf area}

The number of leaves (NoL) were counted manually. The measurement for total leaves area (TLA) was done using leaf area meter. The measurements were done by placing the leaf on automated rotated conveyer belts to move the leaves across the scanning bed and enable data collection from the same plant by recording individual leaves area and directly computing cumulative area for a group of leaves (An \& Shangguan, 2008; Oyedeji et al., 2014).

\section{Leaf gas exchange rate}

The measurement was obtained from LI-COR ${ }^{\circledR}$ Environmental with closed infrared gas analyzer. The measurements were carried out using fully expanded young leaves numbered three and four from plant apex to record photosynthetic carbon assimilation rate (Photo) and stomatal conductance to water rate (Cond). The unit of photosynthetic rate and stomatal conductance used were $\mathrm{mol} \mathrm{H}_{2} \mathrm{O} \mathrm{m}^{-2} \mathrm{~s}^{-1}$ and $\mu \mathrm{mol} \mathrm{CO}_{2} \mathrm{~m}^{-2} \mathrm{~s}^{-1}$, respectively. The data were stored in LI-COR ${ }^{\circledR}$ Environmental console and analyzed by Photosyn Assistant software (Ibrahim et al., 2014; Tamayo et al., 2001).

\section{Plant water potential rate}

The measurement was obtained from pressure chamber instrument. The measurements were carried out using fully expanded young leaves numbered three and four from plant apex to record plant water potential rate (PWP). The leaf was cut from the stem and placed in a chamber with the cut petiole surface $(0.5 \mathrm{~cm})$ protruding through the rubber chamber lid. Pressure was applied to the leaf in the chamber and reading was taken when first water appeared on the cut surface of the petiole. The unit of water potential used was Mpa (Jamaludin et al., 2015).

\section{Chlorophyll fluorescence rate}

The measurements were carried out using fully expanded young leaves numbered three and four from plant apex to record plant chlorophyll fluorescence rate (CF). The leaves were darkened for $15 \mathrm{~min}$. by attaching the light-exclusion clips to the central region of leaf surface. The rate was 
measured using portable chlorophyll fluorescence meter. Measurements were recorded up for $5 \mathrm{~s}$. The unit of quantum efficiency rate used was Fv/Fm (Filipović et al., 2013; Ibrahim et al., 2017; Murchie \& Lawson, 2013).

\section{Total chlorophyll contents}

Total chlorophyll content (TChlC) was measured spectrophotometrically using fresh weight basis (Loh et al., 2002). Only fully expanded young leaves numbered three and four from plant apex were used. Leaf disk of $3 \mathrm{~mm}$ in diameter was obtained using puncher to acquire 15 consistent sizes. The leaf disks were immersed and incubated in $20 \mathrm{~mL}$ of $80 \%$ acetone for homogenization in an aluminum foil-covered glass bottle for approximately $24 \mathrm{~h}$ at $5^{\circ} \mathrm{C}$ until the green color bleached out. Finally, $15 \mu \mathrm{L}$ solution was transferred into 96 well plate to determine the absorbance of chlorophyll a (Chl a), chlorophyll b $(\mathrm{Chl} \mathrm{b})$, and carotenoids (Car) using UV-vis spectrophotometer at wavelengths of 645, 662 and $470 \mathrm{~nm}$ optical density (OD), respectively. The Chl a, Chl b and Car content was calculated as $\mu \mathrm{g} \mathrm{g}^{-1}$ fresh weight as per standard equations recommended (Ibrahim et al., 2017; Ibrahim et al., 2011; Sim et al., 2015).

\section{Total carbohydrate content}

Total carbohydrate content (TCC) was measured spectrophotometrically using Anthrone and Hofreiter method (Hansen \& Moller, 1975). The samples were weighed at $1 \mathrm{~g}$ into $50 \mathrm{~mL}$ conical tube. Then, it was hydrolyzed by keeping it in boiling water bath for three hours with $5 \mathrm{~mL}$ of $2.5 \mathrm{M}$ hydrochloric acid and cool to room temperature. Next, it was neutralized with solid sodium carbonate until the effervescence ceases. Following that, the volume was made up to $50 \mathrm{~mL}$ and centrifuged at 5,000 rpm for $5 \mathrm{~min}$. The supernatant was separated and filtered with filter paper. The $1 \mathrm{~mL}$ aliquot was taken for analysis. The standards [liquid chromatography-grade glucose $(\mathrm{G})$ ] were prepared by taking 0.0 (serves as blank), $0.2,0.4,0.6,0.8$ and $1 \mathrm{~mL}$ of the working standard. The volume was made up to 1 $\mathrm{mL}$ in all tubes including the sample tubes by adding distilled water. Next, the tubes were cooled on ice before ice-cold Anthrone reagent was added. Then, $4 \mathrm{~mL}$ of Anthrone reagent was added and heated for $8 \mathrm{~min}$. in boiling water bath.
The blanks used were absolute methanol. Finally, they were cooled rapidly, then $15 \mu \mathrm{L}$ solution was transferred into 96 well plate and the sample absorbance were read at $630 \mathrm{~nm}$ using UV-vis spectrophotometer. A standard curve graph was drawn by plotting concentration of the stock solution versus sample absorbance readings. The quantification of carbohydrate present was calculated according to the formulation (Ibrahim et al., 2017; Ibrahim et al., 2012; Ibrahim et al., 2011; Ibrahim \& Jaafar, 2012; Khalid, 2006). The TCC in sample was expressed as $\mathrm{mg} \mathrm{G}$ equivalent $\mathrm{g}^{-1}$ dry sample.

\section{Total protein content}

Total protein content (TPrC) was measured spectrophotometrically using Lowry method (John, 1995). The samples were weighted at $1 \mathrm{~g}$ into $50 \mathrm{~mL}$ conical tube and extracted with $10 \mathrm{~mL}$ of $100 \%$ methanol at room temperature for $24 \mathrm{~h}$ and centrifuged at 7,000 $\mathrm{rpm}$ for $10 \mathrm{~min}$. The supernatant separated and filtered with filter paper. Then, $0.2 \mathrm{~mL}$ of extract was pipetted out and the volume was made up to $1 \mathrm{~mL}$ with distilled water. The $5 \mathrm{~mL}$ of alkaline copper reagent was added to all tubes and it allowed stand for $10 \mathrm{~min}$. Then, $0.5 \mathrm{~mL}$ of Folin's Ciocalteau reagent was added and incubated in the dark for $30 \mathrm{~min}$. The blanks used were absolute methanol. Finally, $15 \mu \mathrm{L}$ solutions were transferred into 96 well plates to determine the absorbance. The intensity of color developed was read at $660 \mathrm{~nm}$ using UV-vis spectrophotometer. Beforehand, the standards [liquid chromatography-grade bovine serum albumin (BSA)] were prepared by dissolving $20 \mathrm{mg}$ BSA in $10 \mathrm{~mL}$ of the same diluents for the samples. Then, they were diluted to $200,400,600,800,1,000$ and $1,200 \mu \mathrm{g} / \mathrm{mL}$. A standard curve graph was drawn by plotting concentration of the stock solution versus sample absorbance readings. The quantification of protein present in the sample tube was calculated (Ibrahim et al., 2011; Khalid, 2006; Lowry et al., 1951, 2000). The TPrC in the samples was expressed as mg BSA equivalent $\mathrm{g}^{-1}$ dry sample.

\section{Total lipid content}

Total lipid content (TLiC) was measured using Folch method (Shams et al., 2015). Well ground sample was weighed $1 \mathrm{~g}$ into $50 \mathrm{~mL}$ conical tube and extracted with chloroform and methanol (2:1, 
$\mathrm{v} / \mathrm{v})(20 \mathrm{~mL})$ for homogenization at room temperature for $24 \mathrm{~h}$ and centrifuged at 7,000 rpm for $10 \mathrm{~min}$. Lipid extract was purified to eliminate contaminants by pouring the extracts into a beaker through filter paper containing activated charcoal to remove coloring matters. A clear supernatant obtained was then further purified with $0.2 \mathrm{~mL}$ of aqueous $0.9 \%(\mathrm{w} / \mathrm{v})$ sodium chloride. Purified lipids were transferred into evaporated and concentrated dryness at $40^{\circ} \mathrm{C}$, and the residue was weighed. Quantification of crude lipid was performed based on dry weighed determination. The weight of extract gives TLiC which was expressed as $\mathrm{mg}^{-1}$ dry sample (Ibrahim et al., 2017, 2014; Jaafar et al., 2012; Sasikala et al., 2013).

\section{Total phenolic content}

Total phenolic content (TPC) was measured spectrophotometrically using Folin-Ciocalteu colorimetric assay method (Lowry et al., 1951). The samples were weighted $1 \mathrm{~g}$ into $50 \mathrm{~mL}$ conical tube and extracted with $10 \mathrm{~mL}$ of $100 \%$ methanol at room temperature for $24 \mathrm{~h}$ and centrifuged at 7,000 $\mathrm{rpm}$ for $10 \mathrm{~min}$. The supernatant was separated and filtered with filter paper. Then, 1 $\mathrm{mL}$ of extract was pipetted out into $15 \mathrm{~mL}$ conical tube and $2 \mathrm{~mL}(10 \% \mathrm{v} / \mathrm{v})$ of Folin-Ciocalteu reagent was added to the extract sample and incubated for five min. Later, $1.6 \mathrm{~mL}(7.5 \%)$ of sodium carbonate solution was added into the sample. The sample mixture was then vortexed and incubated in the dark for one hour at room temperature. The blanks used were absolute methanol. Finally, $15 \mu \mathrm{L}$ solutions were transferred into 96 well plates to determine the absorbance. The absorbance of the samples was measured at $760 \mathrm{~nm}$ using UV-vis spectrophotometer. Beforehand, a series of standard solutions [liquid chromatography-grade caffeic acid (CA)] (0.1 to $2 \mathrm{mg} / \mathrm{mL}$ ) were prepared. A standard curve graph was drawn by plotting concentration of the stock solution versus the sample absorbance readings. The quantification of phenolic present in the sample tube was then calculated (Ibrahim et al., 2017; Morat, 2013; Rosidah et al., 2008; Shirazi et al., 2014; Teoh et al., 2016). The TPC in sample was expressed as $\mathrm{mg}$ caffeic acid equivalents, CAE, in $m g g^{-1}$ dry sample.

\section{Total flavonoid content}

Total flavonoid content (TFC) was measured spectrophotometrically using aluminum chloride complex colorimetric assay method (Kaewseejan \& Siriamornpun, 2015; Krishnan et al., 2015; Mongkhonsin et al., 2016; Wu et al., 2011). The samples were weighed $1 \mathrm{~g}$ into $50 \mathrm{~mL}$ conical tube and extracted with $10 \mathrm{~mL}$ of $100 \%$ methanol at room temperature for $24 \mathrm{~h}$ and centrifuged at 7,000 $\mathrm{rpm}$ for $10 \mathrm{~min}$. The supernatant was separated and filtered with filter paper. Then, 1 $\mathrm{mL}$ of extract was pipetted out into $15 \mathrm{~mL}$ conical tube, mixed with $5 \mathrm{~mL}$ of distilled water and 0.3 $\mathrm{mL}$ of $5 \%$ sodium nitrite solution. They were mixed well and allowed to stand for $6 \mathrm{~min}$. Then, $0.6 \mathrm{~mL}$ of $10 \%$ aluminum chloride solution was added. After $5 \mathrm{~min}, 2 \mathrm{~mL}$ of $1 \mathrm{M}$ sodium hydroxide was added to the mixture and made up to $10 \mathrm{~mL}$ with distilled water. The blanks used were absolute methanol. Finally, $15 \mu \mathrm{L}$ solutions were transferred into 96 well plates to determine the absorbances. The absorbance of the samples was measured at $510 \mathrm{~nm}$ using UV-vis spectrophotometer. Beforehand, a series of standard solutions [liquid chromatography-grade kaempferol $(\mathrm{K})$ ] (0.04 to $1.80 \mathrm{mg} / \mathrm{mL}$ ) were prepared. A standard curve graph was drawn by plotting the concentration of the stock solution versus the sample absorbance readings. The quantification of flavonoid present in the sample tube was then calculated (Kaewseejan et al., 2015; Morat, 2013; Seow et al., 2014; Shirazi et al., 2014; $\mathrm{Yu}$ et al., 2010). The TFC in the sample was expressed as $\mathrm{mg}$ kaempferol equivalents, $\mathrm{KE}$, in $\mathrm{mg} / \mathrm{g}$ dry sample.

\section{Quantification of phenolic and flavonoid Preparation of plant extract}

Well ground sample was weighed $1 \mathrm{~g}$ into $50 \mathrm{~mL}$ conical tube and extracted with $10 \mathrm{~mL}$ of $100 \%$ methanol at room temperature for $24 \mathrm{~h}$, sonicated at normal mode for $5 \mathrm{~min}$. and centrifuged at 7,000 $\mathrm{rpm}$ for $10 \mathrm{~min}$. The supernatant was separated and filtered with filter paper. The methanolic-extract was transferred into evaporated and concentrated dryness at $40^{\circ} \mathrm{C}$ using rotary evaporator. It was weighed, redissolved in $1.5 \mathrm{~mL}$ liquid chromatographygrade methanol and filtered through sterile membrane filter, $0.45 \mu \mathrm{m} ; 25 \mathrm{~mm}$ in $2 \mathrm{~mL}$ amber glass HPLC vials and ready for further 
chromatographic analysis (Akowuah et al., 2009; Kaewseejan et al., 2015; Li et al., 2016; Rivai et al., 2011; Yan et al., 2014; Yu et al., 2010).

\section{Thin layer chromatography}

The stationary phase used was $20 \times 20 \mathrm{~cm}, 0.25$ $\mathrm{mm}$ TLC plate pre-coated with silica gel $60 \mathrm{~F}_{254}$ on aluminum sheets and the mobile phase used was a mixture of toluene, ethyl acetate and formic acid (5:4:1). Marker or reference compounds used were caffeic acid, cinnamic acid, chlorogenic acid, gallic acid, ferulic acid and vanillic acid for phenolic compounds. Meanwhile, kaempferol, quercetin, myricetin and rutin for flavonoid compounds (Iskander et al., 2002; Ismail et al., 2015; Ismail et al., 2017; Sasidharan et al., 2011). The $10 \mu \mathrm{L}$ of each tested sample and reference compound were applied as $6 \mathrm{~mm}$ band, $2 \mathrm{~mm}$ apart, $10 \mathrm{~mm}$ from the lower, upper, left, and right edges of the plate using microsyringe. In the glass tank, $50 \mathrm{~mL}$ developing solvent was poured and allowed to saturate for 5 to $10 \mathrm{~min}$. in room temperature. Migration (as in linear ascending development) distance of the developing solvent on the plate was $80 \mathrm{~mm}$ from lower edge of the plate or equivalent to the time allowed for the development and maximal separation of the active compounds present in the samples was 15 to $25 \mathrm{~min}$. The plates were then dried at $100^{\circ} \mathrm{C}$ using forced draft oven for 3 to $5 \mathrm{~min}$. The dried plates were visualized under UV light at 254 and $366 \mathrm{~nm}$ OD. The color and distance of unknown spots were compared with marker or reference compound. The retention factor $\left(\mathrm{R}_{\mathrm{f}}\right)$ values were calculated using formula of migration distance of sport/migration distance of solvent (Iskander et al., 2002; Ismail et al., 2017; $\mathrm{Ng}$ et al., 2013; Sasidharan et al., 2011).

\section{High-performance liquid chromatography}

The HPLC-grade purity chemicals and reference compounds used for authenticated standards were methanol, acetonitrile, orthophosphoric acid $85 \%$, caffeic acid, cinnamic acid, chlorogenic acid, gallic acid, ferulic acid and vanillic acid for phenolic analysis, and kaempferol, quercetin, myricetin and rutin for flavonoid analysis. The linear standard curves were constructed by injecting caffeic acid and kaempferol for phenolic and flavonoid analysis, respectively. Filtered water was obtained from ultrapure water purification system. The reference stock solutions were filtered through sterile membrane filter, $0.45 \mu \mathrm{m}$; $25 \mathrm{~mm}$ in $2 \mathrm{~mL}$ amber glass HPLC vials, and stored at $5^{\circ} \mathrm{C}$ (Giedyk, 2011; Olkowski et al., 2003; Zulkifle, 2006).

The system was equipped with Waters ${ }^{\circledR}$ 600E Multisolvent Delivery System, USA consisting of UV/Visible detector, degasser, autosampler and Waters Empower 3 software. Separation was achieved on reversed phase (RP) column [RP-18e $(100 \times 4.6 \mathrm{~mm}$ i.d; $2 \mu \mathrm{m})$, Semiprep, Particle size 0 $\mu \mathrm{m}$, Pore size $130 \AA$ ] preceded by C18 guard column at $40^{\circ} \mathrm{C}$ with diode array detector (DAD) set at 190 to $600 \mathrm{~nm}$ and $(0.1 \%)$ orthophosphoric acid 85\% (eluent A): acetonitrile (eluent B) (90.5:9.5, v/v isocratically) were employed as eluent for phenolic analysis, and orthophosphoric acid 85\% (eluent A): methanol (eluent B) (60:40, $\mathrm{v} / \mathrm{v}$ isocratically) were employed as eluent for flavonoid analysis. The column was washed with $100 \%$ methanol for $10 \mathrm{~min}$, the initial conditions were again applied, the system was monitored for $30 \mathrm{~min}$ and the column was allowed to equilibrate with $(0.1 \%)$ orthophosphoric acid $85 \%$ : acetonitrile (90.5:9.5, v/v isocratically) for $35 \mathrm{~min}$, being 75 min total consuming time of run for phenolic analysis, and orthophosphoric acid 85\%: methanol (60:40, v/v isocratically) for $35 \mathrm{~min}$, being 75 min total consuming time of run for flavonoid analysis. For phenolic analysis, oven temperature was $40^{\circ} \mathrm{C}$. The flow rate was kept

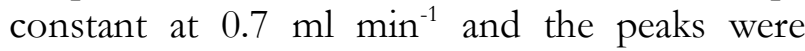
simultaneously identified using UV absorbance at $327 \mathrm{~nm}$ for caffeic acid. The injection volume was $1 \mu \mathrm{l}$ (standard compound) and $10 \mu \mathrm{l}$ (sample) for each technical repeat automatically. Meanwhile, for flavonoid analysis, oven temperature was set at $35^{\circ} \mathrm{C}$. The flow rate was kept constant at $1 \mathrm{ml}$ $\min ^{-1}$ and the peaks were simultaneously identified using UV absorbance at 250 to $360 \mathrm{~nm}$ for kaempferol. The injection volume was $10 \mu \mathrm{l}$ (standard compound and sample) for each technical repeat automatically. The chromatographic peaks of the analytes were confirmed by comparing the retention time and UV spectra with pure standards. Quantification was carried out by integration of the peak using external standard method. The procedure was performed separately for each standard (Ashokkumar et al., 2013; Bellés et al., 2006; Kaewseejan \& Siriamornpun, 2015; Rivai et al., 
2011; Shoeva et al., 2016; Yi et al., 2016a, 2016b; Yu et al., 2010; Zulkifle, 2006).

\section{Statistical analysis}

The collected data were subjected to analysis of variance (ANOVA) and correlation using $\mathrm{SAS}^{\circledR}$ 9.4 software (Version 8.0, SAS Institute Inc., and Cary, NC, USA.). The analyses were done in triplicate and expressed as mean $(n=3) \pm$ standard error (SE) from the dependent treatments (Jaafar et al., 2012). All variables from measurements were analyzed using General Linear Model with N, K and ER supply managements. Any differences between treatment means were analyzed by two-way analysis and compared using Duncan's multiple range test (DMRT) at $\mathrm{p}$ value $\leq 0.05$ levels. The regression model that best fitted the data as evaluated by an F-test, was chosen.

\section{RESULTS}

\section{Total plant dry weight, number of leaf and total leaf area}

The TPDW was affected by $\mathrm{H}$ time and statistically consistent in all treatments; increased with increasing harvesting time and no significant difference $(\mathrm{p} \leq 0.05)$ with decreasing rate of ER including the control plants (Tables 1 and 2, and Figure 1). Biomass dry weight was highest at Week 12 compared to Week 4. However, there was no significant difference in all ER treatments. All interaction treatments were statistically not significant $(\mathrm{p} \leq 0.05)$, but significantly different $(p \leq 0.05)$ in harvesting time (Figure 1). The event was probably because of the total accumulated $\mathrm{N}$, $\mathrm{K}$ and $\mathrm{ER}$ rates have forced the plants to grow in linear increase with their weight. The weight was controlled directly by the rates of N, K, ER and harvesting time (Marchese et al., 2010; Treder, 2008). However, the biomass dry weights was decreased as plant water deficit increases (Rahimi et al., 2013). This is inferred by the results when weight has no significance difference in all ER treatments except in harvesting time. Measurement of TPDW is one of the parameters that is best used as indicator in plant growth and biomass production resulting in weight gain. Total plant biomass is best considered as the embodiment of all processes and events that occur during plant growth. The effect of N, K and ER rates as well as $\mathrm{H}$ time on NoL and TLA were also recorded (Tables 1 and 2).

\section{Leaf gas exchange rate}

The Photo was affected by $\mathrm{H}$ time and statistically consistent in all treatments, however, decreased with increasing harvesting time and no significant difference $(p \leq 0.05)$ with decreasing ER rate including the control plants (Tables 1 and 2, and Figure 2). The Photo was highest at Week 4 and lowest at Weeks 8 and 12. The interaction treatment was statistically not significant $(p \leq 0.05)$, however, there were significant difference $(p \leq 0.05)$ in harvest time (Figure 2). Meanwhile, the measurements of Photo were not significantly correlated with Cond at $\mathrm{r}=-0.037$; $\mathrm{p} \geq 0.05$ by a linear function (Table 4). The event was probably because of Photo was affected by $\mathrm{K}$ concentrations, which ultimately determined the overall yield (Chen et al., 2013). Photosynthesis is related to carbon assimilation and dry matter production and that chlorophyll content and stomatal conductance are the major factors determining the Photo (Hill et al., 2011). However, the result has shown no significance difference in $\mathrm{N}$ and $\mathrm{K}$ interaction treatment on Photo. The reduction in cellular hydration would cause source limitation of Photo due to lower stomatal conductance in water deficit plants (Fonseca et al., 2006). However, the result showed no significance difference in all ER treatments on Photo. The reduction of Photo might be due to $\mathrm{K}$ deficiency (Chen et al., 2013). Nevertheless, the result showed no significance difference in $\mathrm{K} 0$ and K30 treatments when ER treatment were also not significant in Photo.

The Cond was affected by interaction treatment of $\mathrm{N}, \mathrm{K}$, and $\mathrm{ER}$ rates, and $\mathrm{H}$ time (Tables 1 and 2, and Figure 3). The Cond was statistically significant in all treatments with increasing harvesting time $(\mathrm{p} \leq 0.05)$. The $75(\%$ $\mathrm{ER})$ in N0K30 treatment $(0 \mathrm{~kg} \mathrm{~N} / \mathrm{ha}$ and $30 \mathrm{~kg}$ $\mathrm{K} / \mathrm{ha})$ and $100(\% \mathrm{ER})$ in N90K0 (90 kg N/ha and $0 \mathrm{~kg} \mathrm{~K} / \mathrm{ha}$ ) have shown the highest Cond, meanwhile, 50 (\% ER) in N0K30 and 75 (\% ER) in N90K0 have shown the lowest Cond. The Cond was highest under 75 (\% ER) in N0K30 at Week 12 compared to 100 (\% ER) in N90K0 at Week 8 (Figure 3). The Cond was constantly increased with increasing harvesting time in both 
treatments, and the measurements of Cond were not significantly correlated with Photo at $r=$ 0.037; $\mathrm{p} \geq 0.05$ by a linear function (Table 4). The event was probably because of reduction in cellular hydration that cause source limitation of photosynthesis due to lower Cond (0.004-0.18 mol $\mathrm{H}_{2} \mathrm{O} \mathrm{m}^{-2} \mathrm{~s}^{-1}$ in $25 \%$ ER compared to 0.003 $0.20 \mathrm{~mol} \mathrm{H}_{2} \mathrm{O} \mathrm{m}^{-2} \mathrm{~s}^{-1}$ in $\left.100 \% \mathrm{ER}\right)$ in water deficit plants (Kleinwächter \& Selmar, 2014). In addition, $\mathrm{K}$ has increased plant's drought resistance through its functions in stomatal regulation when Cond was highest under $75(\%$ ER) in N0K30 compared to 100 (\% ER) in N90K0 (Said-Al Ahl \& Hussein, 2010). Meanwhile, $\mathrm{K}$ also controls the Cond because the concentration gradient of $\mathrm{K}$ in internal and external of stomatal guard cells is affecting the solute potential in plant cells (Chen et al., 2013).

Table 1. Probability of Greater $\mathrm{F}(\mathrm{P}>\mathrm{F})$ for the ANOVA on effect of $\mathrm{N}, \mathrm{K}$ and $\mathrm{ER}$ rates, and $\mathrm{H}$ time on growth, physiology and biochemical assay variables.

\begin{tabular}{|c|c|c|c|c|c|c|c|c|}
\hline Source & NK & ER & $\mathbf{H}$ & NK x ER & $\begin{array}{c}\text { NK } x \\
\mathbf{H}\end{array}$ & $\mathrm{ER} \times \mathrm{H}$ & NK $\times$ ER x H & $\mathrm{CoV}$ \\
\hline Df & 1 & 3 & 2 & 3 & 2 & 6 & 6 & \\
\hline TPDW & ns & ns & $* * * *$ & $*$ & ns & ns & ns & 28.399 \\
\hline NoL & ns & ns & $* * * *$ & ns & ns & ns & $*$ & 17.322 \\
\hline TLA & ns & ns & $* * * *$ & ns & ns & ns & ns & 35.104 \\
\hline Cond & $* *$ & $* * * *$ & $* * * *$ & $* * *$ & $* * * *$ & $* * * *$ & $* * * *$ & 15.191 \\
\hline Photo & ns & ns & $* * * *$ & $*$ & $* *$ & ns & ns & 41.464 \\
\hline $\mathrm{CF}$ & $* * * *$ & $* * * *$ & $* * *$ & ns & $* *$ & ** & $*$ & 8.765 \\
\hline PWP & $* * * *$ & $* * * *$ & $* * * *$ & ns & ns & ns & * & 17.713 \\
\hline TChlC & $* * * *$ & $* * * *$ & $* * * *$ & ns & $* *$ & $* * * *$ & $* * * *$ & 2.737 \\
\hline TCC & $*$ & $* *$ & $* * * *$ & ns & ns & $*$ & ns & 9.729 \\
\hline TPrC & $* * * *$ & $* * * *$ & $* * * *$ & $* * * *$ & $* * * *$ & $* * * *$ & $* * * *$ & 3.814 \\
\hline TLiC & ns & $* *$ & $*$ & $* *$ & ns & ns & ns & 48.295 \\
\hline TPC & ns & ns & $* * * *$ & $*$ & $* * * *$ & $* * * *$ & $\mathrm{~ns}$ & 14.454 \\
\hline TFC & $* * *$ & $* * * *$ & $* * * *$ & $* * * *$ & $* * * *$ & $* * * *$ & $* * * *$ & 7.082 \\
\hline \multicolumn{9}{|c|}{ 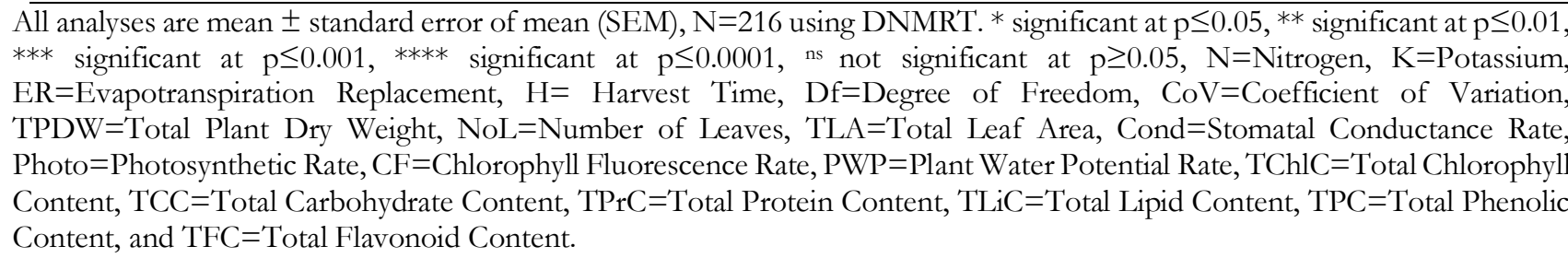 } \\
\hline
\end{tabular}


Table 2. Effect of treatments and harvest time on growth and physiology variables.

\begin{tabular}{|c|c|c|c|c|c|c|c|}
\hline & TPDW & NoL & TLA & Photo & Cond & $\mathrm{CF}$ & PWP \\
\hline \multicolumn{8}{|l|}{$\mathrm{NK}$} \\
\hline N0K30 & $1.087 \mathrm{a}$ & $28.250^{a}$ & $534.08^{a}$ & $3.131^{\mathrm{a}}$ & $0.090^{\mathrm{a}}$ & $0.525^{b}$ & $0.767 b$ \\
\hline N90K0 & $1.047 \mathrm{a}$ & $28.361^{a}$ & $519.36^{a}$ & $3.627^{a}$ & $0.081^{\mathrm{b}}$ & $0.599 \mathrm{a}$ & $0.982^{\mathrm{a}}$ \\
\hline \multicolumn{8}{|l|}{ ER } \\
\hline 100 & $1.004^{a}$ & $28.889^{a}$ & $528.40^{a}$ & $3.362^{\mathrm{a}}$ & $0.088^{a}$ & $0.772^{\mathrm{a}}$ & $0.725^{c}$ \\
\hline 75 & $1.064^{\mathrm{a}}$ & 29.389 a & $558.90^{a}$ & $3.342^{\mathrm{a}}$ & $0.093^{a}$ & $0.660^{\mathrm{b}}$ & $0.810^{\mathrm{bc}}$ \\
\hline 50 & $1.206^{\mathrm{a}}$ & $27.389 a$ & $516.01^{a}$ & $3.144^{\mathrm{a}}$ & $0.071^{\mathrm{b}}$ & $0.506^{c}$ & $0.911^{\mathrm{b}}$ \\
\hline 25 & $0.992^{\mathrm{a}}$ & $27.556^{\mathrm{a}}$ & $503.55^{a}$ & $3.668^{\mathrm{a}}$ & $0.088^{\mathrm{a}}$ & $0.311^{\mathrm{d}}$ & $1.053^{\mathrm{a}}$ \\
\hline \multicolumn{8}{|l|}{$\mathrm{H}$} \\
\hline Week 4 & $0.517 \mathrm{c}$ & $19.292^{c}$ & $175.47 \mathrm{~b}$ & $4.817^{a}$ & $0.049 \mathrm{c}$ & $0.561^{b}$ & $0.890^{\mathrm{a}}$ \\
\hline Week 8 & $0.748^{\mathrm{b}}$ & $34.708^{a}$ & $658.85^{a}$ & $2.461^{\mathrm{b}}$ & $0.057^{b}$ & $0.596^{\mathrm{a}}$ & $0.760^{\mathrm{b}}$ \\
\hline Week 12 & $1.935^{\mathrm{a}}$ & $30.917 \mathrm{~b}$ & $745.83^{\mathrm{a}}$ & $2.859^{\mathrm{b}}$ & $0.149^{a}$ & $0.529 \mathrm{c}$ & $0.975^{\mathrm{a}}$ \\
\hline \multicolumn{8}{|l|}{ Interaction } \\
\hline $\mathrm{NK}$ & $0.578^{\mathrm{ns}}$ & $0.924^{\mathrm{ns}}$ & $0.737 \mathrm{~ns}$ & $0.140^{\mathrm{ns}}$ & $0.005^{* *}$ & $<.0001 * * * *$ & $<.0001 * * * *$ \\
\hline ER & $0.144^{\mathrm{ns}}$ & $0.541^{\mathrm{ns}}$ & $0.828^{\mathrm{ns}}$ & $0.733^{\text {ns }}$ & $<.0001 * * * *$ & $<.0001 * * * *$ & $<.0001 * * * *$ \\
\hline $\mathrm{H}$ & $<.0001 * * * *$ & $<.0001 * * * *$ & $<.0001 * * * *$ & $<.0001 * * * *$ & $<.0001 * * * *$ & $0.0001 * * *$ & $<.0001 * * * *$ \\
\hline NKxER & $0.013^{*}$ & $0.263^{\mathrm{ns}}$ & $0.362^{\mathrm{ns}}$ & $0.043^{*}$ & $0.0003^{* * *}$ & $0.167^{\mathrm{ns}}$ & $0.336^{\mathrm{ns}}$ \\
\hline $\mathrm{NKxH}$ & $0.410^{\mathrm{ns}}$ & $0.867 \mathrm{~ns}$ & $0.678^{\mathrm{ns}}$ & $0.004 * *$ & $<.0001^{* * * *}$ & $0.009 * *$ & $0.287^{\mathrm{ns}}$ \\
\hline ERxH & $0.289^{\mathrm{ns}}$ & $0.641^{\mathrm{ns}}$ & $0.184^{\mathrm{ns}}$ & $0.845^{\text {ns }}$ & $<.0001 * * * *$ & $0.005^{* *}$ & $0.158^{\mathrm{ns}}$ \\
\hline NKxERxH & $0.072^{\mathrm{ns}}$ & $0.028^{*}$ & $0.702^{\mathrm{ns}}$ & $0.666^{\mathrm{ns}}$ & $<.0001^{* * * *}$ & $0.013^{*}$ & $0.015^{*}$ \\
\hline
\end{tabular}

All analyses are mean \pm SEM, $\mathrm{N}=216$ using DNMRT. $*$ significant at $\mathrm{p} \leq 0.05, * *$ significant at $\mathrm{p} \leq 0.01$, *** significant at $\mathrm{p} \leq 0.001$, **** significant at $\mathrm{p} \leq 0.0001$, ns not significant at $\mathrm{p} \geq 0.05, \mathrm{~N}=$ Nitrogen, $\mathrm{K}=$ Potassium, ER=Evapotranspiration Replacement, $\mathrm{H}=$ Harvest Time, TPDW=Total Plant Dry Weight, NoL=Number of Leaves, TLA=Total Leaf Area, Cond=Stomatal Conductance Rate, Photo=Photosynthetic Rate, $\mathrm{CF}=$ Chlorophyll Fluorescence Rate, and PWP=Plant Water Potential Rate.

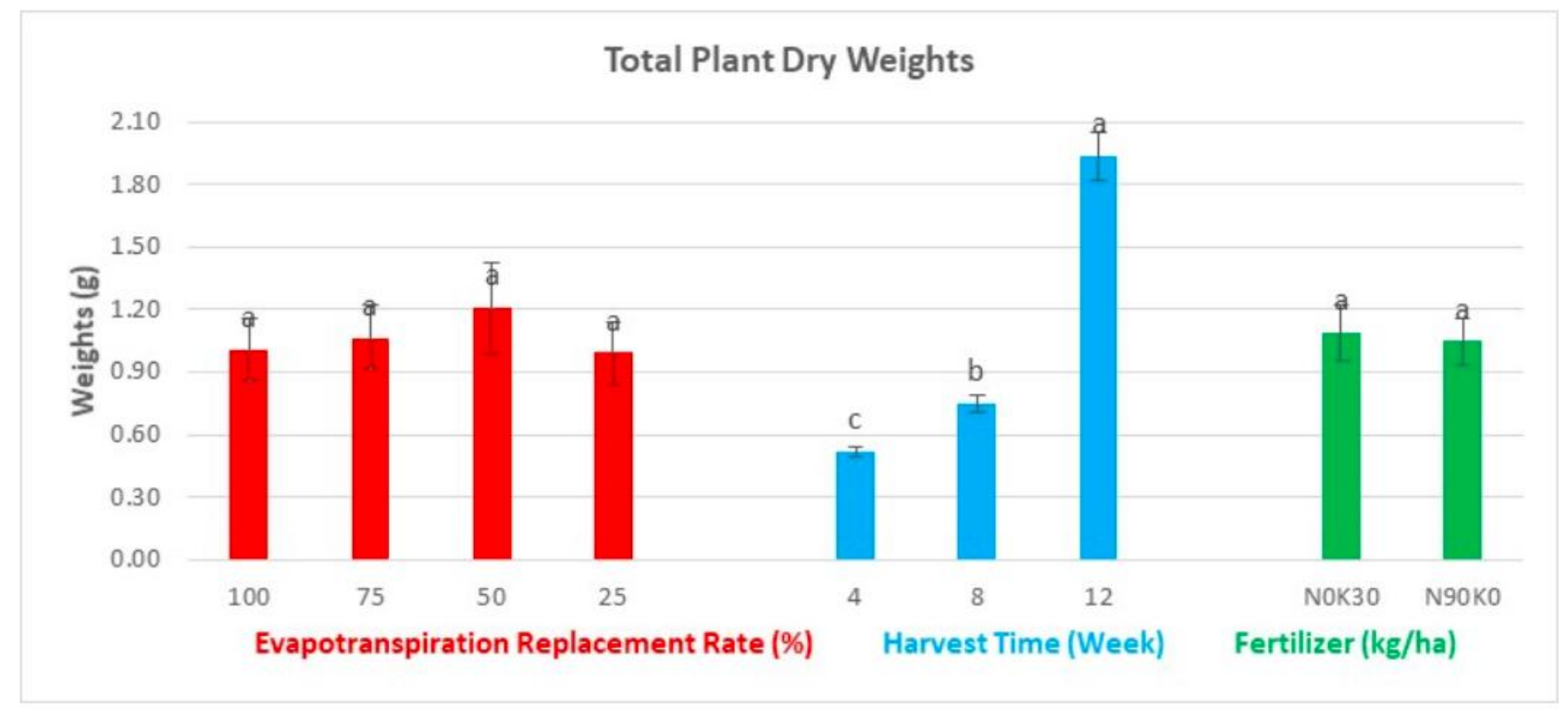

Figure 1. Effect of $\mathrm{N}, \mathrm{K}$ and $\mathrm{ER}$ rates, and $\mathrm{H}$ time on TPDW. Bars represents standard error of differences between the means. $\mathrm{N}=72$. Different letters are means that are significantly different $(\mathrm{p} \leq 0.05)$. 


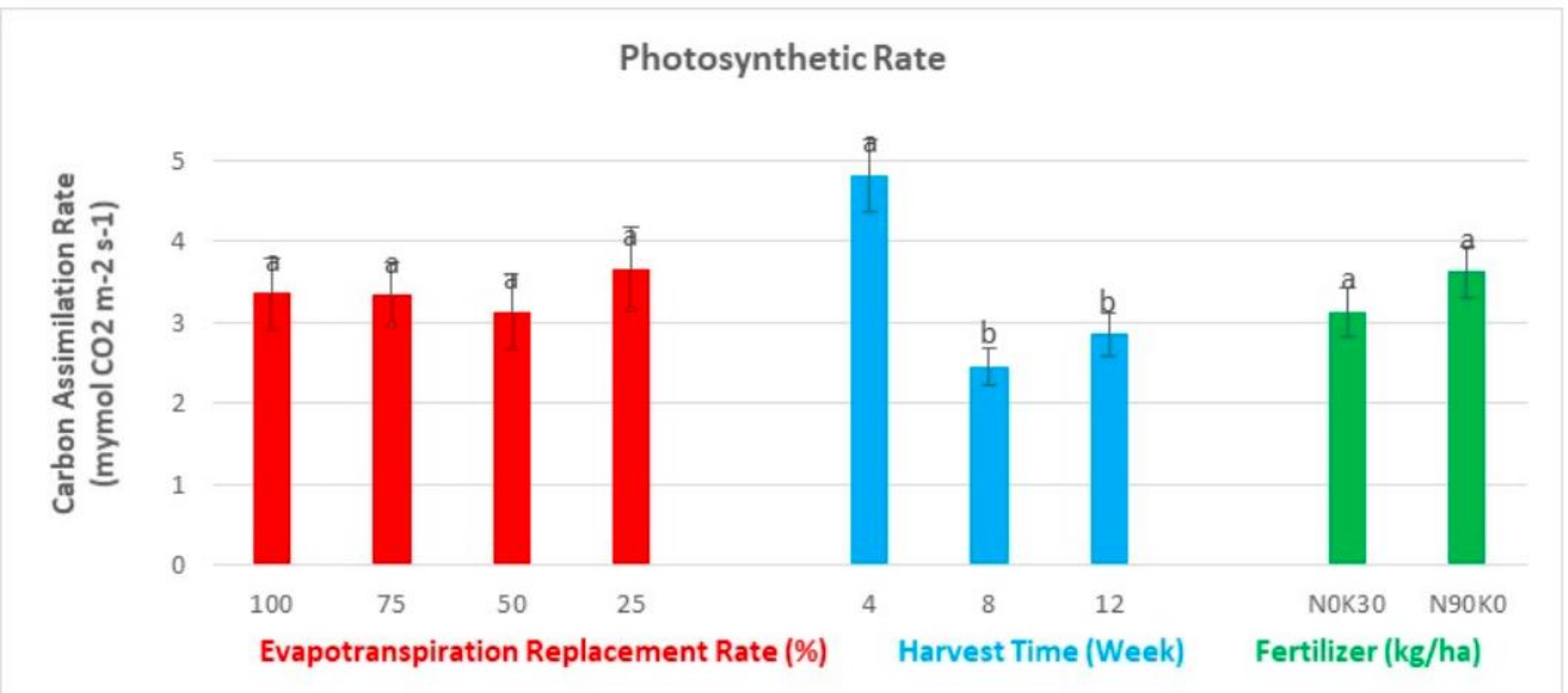

Figure 2. Effect of N, K and ER rates, and $\mathrm{H}$ time on Photo. Bars represents standard error of differences between the means. $N=72$. Different letters are means that are significantly different $(p \leq 0.05)$.

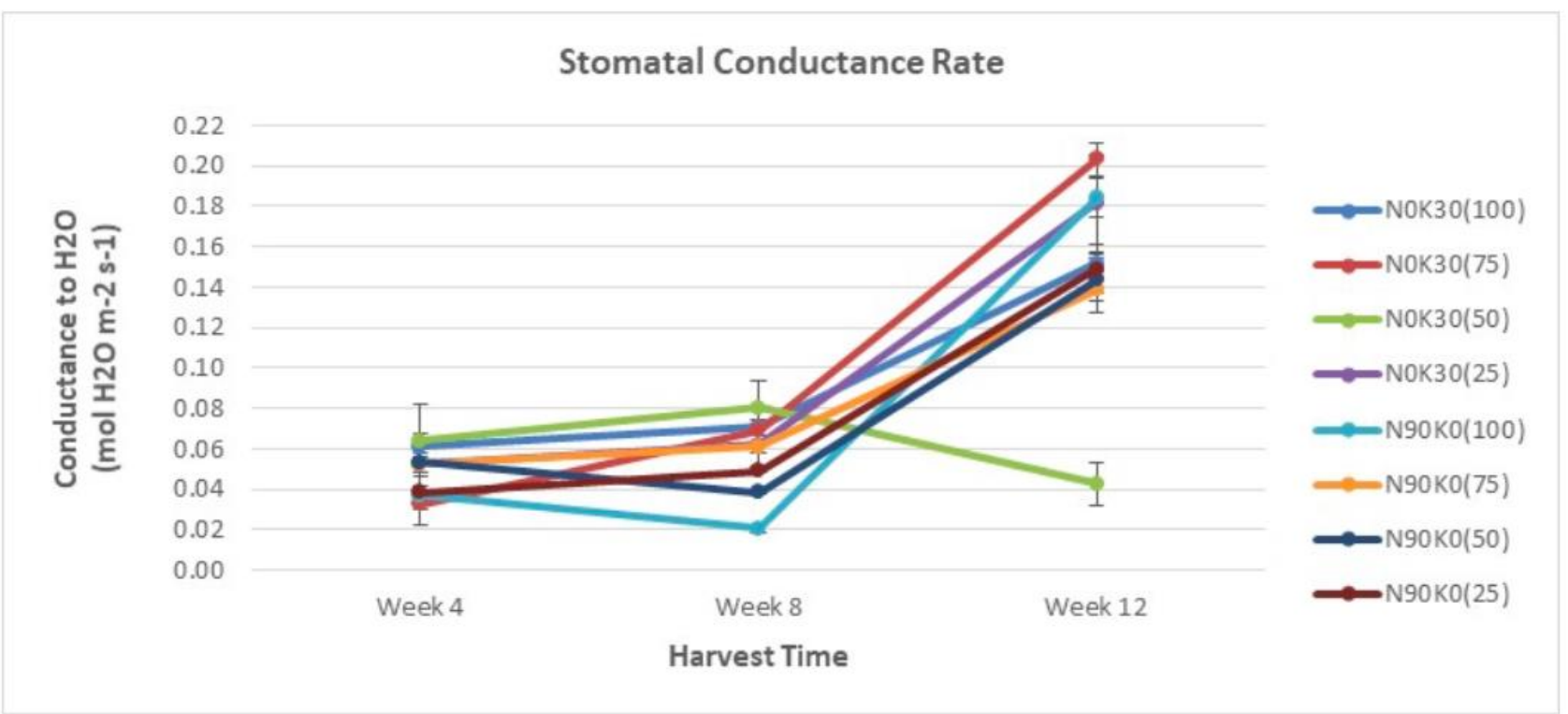

Figure 3. Changes in Cond as affected by the interactions between rates of N, K and ER, and $H$ time. Bars represents standard error of differences between the means $(\mathrm{p} \leq 0.05) . \mathrm{N}=72$.

\section{Chlorophyll fluorescence rate}

The CF was affected by interaction treatment of $\mathrm{N}, \mathrm{K}$ and $\mathrm{ER}$ rates, and $\mathrm{H}$ time (Tables 1 and 2, and Figure 4). The CF was statistically significant in all treatments with increasing harvesting time $(\mathrm{p} \leq 0.05)$. The $100(\% \mathrm{ER})$ in N0K30 treatment $(0$ $\mathrm{kg} \mathrm{N} / \mathrm{ha}$ and $30 \mathrm{~kg} \mathrm{~K} / \mathrm{ha}$ ) and N90K0 (90 kg $\mathrm{N} / \mathrm{ha}$ and $0 \mathrm{~kg} \mathrm{~K} / \mathrm{ha}$ ) have shown the highest $\mathrm{CF}$, meanwhile, 25 (\% ER) in N0K30 and N90K0 have shown the lowest CF. The CF was highest under 100 (\% ER) in both treatments in Week 4 compared to 25 (\% ER) in N90K0 in Week 4
(Figure 4). The CF was slightly increased with rising harvesting time in both treatments, and the measurements of CF were not significantly correlated with Photo and Cond at $\mathrm{r}=-0.0002$; $\mathrm{p} \geq 0.05$ and $\mathrm{r}=-0.048 ; \mathrm{p} \geq 0.05$, respectively by a linear function (Table 4). The event was probably causing the reduction of $\mathrm{CF}$ under high water stress $(25 \%$ ER) in both treatments due to the reduction in effective quantum yield. This indicates that high water stress has reduced the Photo efficiency by reducing the efficiency of light harvesting induction of high respiration. 
Subsequently, low Photo has induced the secondary metabolites synthesis in plants (Rahimi et al., 2013). The result was in accordance with the report when $0.2-0.29 \mathrm{Fv} / \mathrm{Fm}(25 \% \mathrm{ER})$ and $0.7-$ $0.81 \mathrm{Fv} / \mathrm{Fm}(100 \% \mathrm{ER})$ in N0K30, meanwhile $0.02-0.1 \mathrm{Fv} / \mathrm{Fm}(25 \% \mathrm{ER})$ and $0.79-0.81 \mathrm{Fv} / \mathrm{Fm}$ $(100 \% \mathrm{ER})$ in N90K0 (Figure 4).

\section{Plant water potential rate}

The PWP was affected by interaction treatment of $\mathrm{N}, \mathrm{K}$ and ER rates, and $\mathrm{H}$ time (Tables 1 and 2, and Figure 5). The PWP was statistically significant in all treatments with increasing harvesting time $(\mathrm{p} \leq 0.05)$. The $25(\% \mathrm{ER})$ in N0K30 treatment $(0 \mathrm{~kg} \mathrm{~N} / \mathrm{ha}$ and $30 \mathrm{~kg} \mathrm{~K} / \mathrm{ha})$ and N90K0 (90 kg N/ha and $0 \mathrm{~kg} \mathrm{~K} / \mathrm{ha}$ ) have shown the highest PWP, meanwhile, 100 (\% ER) in N0K30 and N90K0 have shown the lowest PWP. The water potential was highest under 25 (\% ER) in both treatments at Week 4 compared to 100 (\% ER) in N0K30 at Week 4 (Figure 5). The water potential was increased with rising harvesting time in both treatments, and the measurements of PWP were not significantly correlated with Photo and Cond at $r=0.190$; $\mathrm{p} \geq 0.05$ and $\mathrm{r}=0.169 ; \quad \mathrm{p} \geq 0.05$, respectively. However, significantly correlated with $\mathrm{CF}$ at $\mathrm{r}=$ $0.419 ; \mathrm{p} \leq 0.001$ by a linear function (Table 4$)$. The event was probably related to cell turgidity which significantly affected by water stress (Schuppler et al., 1998). This is because high water potential will leads to turgidity of cells which requires high force to break into the cells (Armstrong, 1998). This is in accordance with the result when 25\% ER in both treatments have recorded high PWP. In addition, $\mathrm{K}$ has also increases plant's drought resistance through its functions in osmoregulation, energy status, charge balance and homeostasis (Mohd Zain et al., 2014a). Besides, increasing rate of $\mathrm{N}$ will also improve water-use efficiency, alleviate drought stress effects by preventing cell membrane damage and enhance osmoregulation during the plant growth (Rahimi et al., 2013). The results showed that PWP was highest under 25 ( $\% \mathrm{ER})$ in N90K0 compared to $100(\% \mathrm{ER})$ in N0K30 (Figure 5). This infers that well-watered plants require less pressure to pull out water to the stem surface as the plant cells itself are in high water tension condition (Dunford \& Vazquez, 2005).

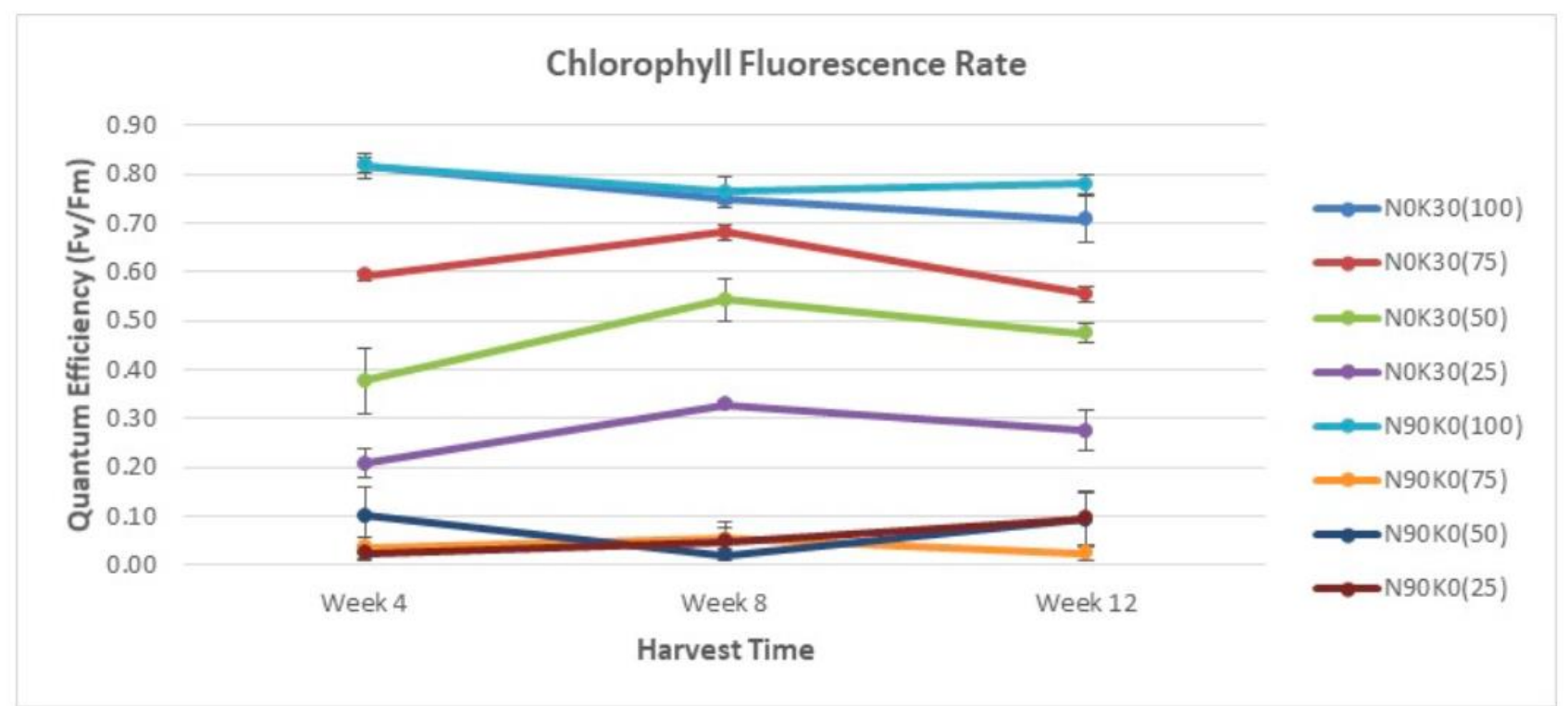

Figure 4. Changes in $\mathrm{CF}$ as affected by the interactions between rates of $\mathrm{N}, \mathrm{K}$ and $\mathrm{ER}$, and $\mathrm{H}$ time. Bars represents standard error of differences between the means $(\mathrm{p} \leq 0.05)$. $\mathrm{N}=72$. 


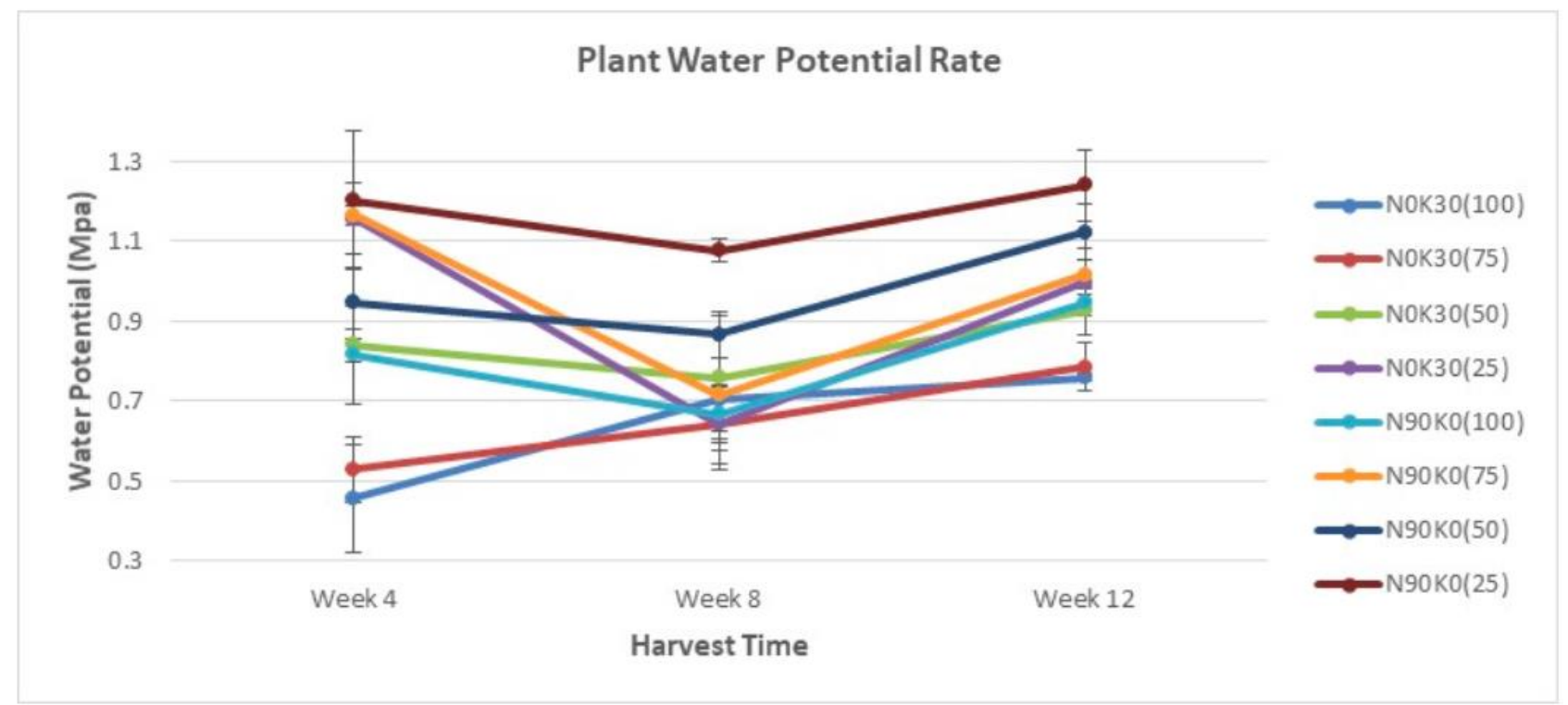

Figure 5. Changes in PWP as affected by the interactions between rates of N, K and ER, and $H$ time. Bars represents standard error of differences between the means $(\mathrm{p} \leq 0.05) . \mathrm{N}=72$.

\section{Total chlorophyll contents}

The TChlC was affected by interaction treatment of $\mathrm{N}, \mathrm{K}$, and $\mathrm{ER}$ rates, and $\mathrm{H}$ time (Tables 1 and 3 , and Figure 6). The TChlC was statistically significant in all treatments with increasing harvesting time $(\mathrm{p} \leq 0.05)$. The $75(\% \mathrm{ER})$ in N0K30 treatment $(0 \mathrm{~kg} \mathrm{~N} / \mathrm{ha}$ and $30 \mathrm{~kg} \mathrm{~K} / \mathrm{ha})$ and $50(\% \mathrm{ER})$ in N90K0 (90 kg N/ha and $0 \mathrm{~kg}$ $\mathrm{K} / \mathrm{ha}$ ) have shown the highest TChlC, meanwhile, 50 (\% ER) in N0K30 and N90K0 have shown the lowest TChlC. The TChlC was highest under 75 (\% ER) in N0K30 at Week 4 compared to 50 (\% ER) in N90K0 at Week 8 (Figure 6). The TChlC was constantly decreased with rising harvesting time in both treatments, and the measurements of TChlC were significantly correlated with Photo at $\mathrm{r}=0.556 ; \mathrm{p} \leq 0.0001$ by a linear function (Table 4). The event was probably related to relative water content in the leaves (Mohd Zain et al., 2014). Moreover, low chlorophyll content will reduce the photosynthetic potential directly and lead to decreases in plants biomass (Murchie \& Lawson, 2013). Enough K concentration will also enhance chlorophyll content and photophosphorylase activity, and maintaining the chloroplast inner membrane and proton gradient of thylakoid membranes, which promote the photosynthetic phosphorylation (Chen et al., 2013). Therefore, the net Photo $\left(0.14-0.20 \mathrm{~mol} \mathrm{H}_{2} \mathrm{O} \mathrm{m}^{-2} \mathrm{~s}^{-1}\right.$ ) (Figure 2) showed in this study may be correlated with high Cond (0.14-2.0 $\mathrm{mol} \mathrm{H}_{2} \mathrm{O} \mathrm{m}^{-2} \mathrm{~s}^{-1}$ ) (Figure 3) and TChlC (7.8-8.3 $\mu \mathrm{g} \mathrm{g}^{-1} \mathrm{FW}$ ) (Figure 6) in both $\mathrm{N} 0 \mathrm{~K} 30$ and N90K0 treatments. Additionally, high or low water supply during plant growth and developmental stage will also decrease the chlorophyll and carotenoids content of the plant (Wang et al., 2016). Meanwhile, moderate supply of water will increase the pigmentation in plant leaf and other organs (Schuppler et al., 1998). However, the results were not in accordance with the reports when 100\% ER was showed 3.9-8.2 $\mu \mathrm{g} \mathrm{g}^{-1} \mathrm{FW}$ and $25 \%$ ER 3.8-8.0 $\mu \mathrm{g} \mathrm{g}^{-1} \mathrm{FW}$, and $50 \%$ ER 3.0 was showed $8.2 \mu \mathrm{g} \mathrm{g}^{-1} \mathrm{FW}$ of TChlC (Figure 6). The chlorophyll content was downregulated under water stress condition, and it may be the signal for increase production of total phenolics, flavonoids and anthocyanins (Fonseca et al., 2006; Jaafar et al., 2012; Ramakrishna \& Ravishankar, 2011). Additionally, there is a negative correlation between secondary metabolites and chlorophyll content which is a sign of gradual switch-off of investment from protein to polyphenols production (Ozdal et al., 2013). The results were justified the reports when TChlC was constantly decrease with rising harvesting time. The chlorophyll content was constantly increased with rising harvesting time, and TPC was highest at Week 12 in both treatments (Figures 6 and 10).

\section{Total carbohydrates content}

The TCC was affected by N, K, and ER rates, and $\mathrm{H}$ time, and statistically significant in all 
treatments (Tables 1 and 3, and Figure 7). The TCC was increased with increasing harvesting time and significantly difference $(p \leq 0.05)$ with decreasing ER rate including the control plants. The TCC was highest at Week 12 compared to the lowest at Week 4. The TCC was increased with rising harvesting time, slightly constant in both $\mathrm{N}$ and $\mathrm{K}$ interaction treatments, and fluctuate in all ER treatments (Figure 7). The measurements of TCC were significantly correlated with Photo, TPrC, TPC and TFC at $\mathrm{r}=-0.360 ; \mathrm{p} \leq 0.01$, $\mathrm{r}=0.745 ; \quad \mathrm{p} \leq 0.0001, \quad \mathrm{r}=0.515 ; \quad \mathrm{p} \leq 0.0001$ and $\mathrm{r}=0.262 ; \mathrm{p} \leq 0.05$, respectively. However, not significantly correlated with $\mathrm{TLiC}$ at $\mathrm{r}=0.218$; $\mathrm{p} \geq 0.05$ by a linear function (Tables 4 and 5 ). The event was probably because of physiologically, concentration of soluble sugar was varied in the plants due to different moisture conditions and nutritional status (Cheng et al., 2014). Drought stress will also increase organic compounds which are required for osmotic adjustment, such as soluble sugars (Cheng et al., 2014; Wang et al., 2015). The result was in accordance with the report when TCC was high at Week 12 compared to Week 4 with no significance difference in decreasing rate of ER, from 100 to 25\% (Figure 7). However, $\mathrm{N}$ deficiencies have promoted accumulation of soluble sugars which has been showed in the result when TCC was slightly high in N0 than in N90 treatment. Meanwhile, K deficiency has reduced the growth more than carbon assimilation, which resulted in accumulation of carbohydrates in the leaves. This response may increase the substrate available for secondary metabolism (Armengaud et al., 2009; Ibrahim et al., 2017). Nevertheless, the results were less significant in K30 (182.912 mg GE/g DW) and K0 (172.856 mg GE/g DW) of TCC (Figure 7). The event was probably related to carbohydrates as the main organic solutes which involved in plant osmotic adjustment and lead to decreases in leaf osmotic potential to maintain turgor. This is an important adaptive mechanism in plants when subjected to deficit irrigation (Hill et al., 2011; Khalid, 2006; Wang et al., 2015). The accumulation of TCC was also related to the reduction in soluble sugar transportation under water stress. However, the result was less significant in relation to TCC and ER treatment.

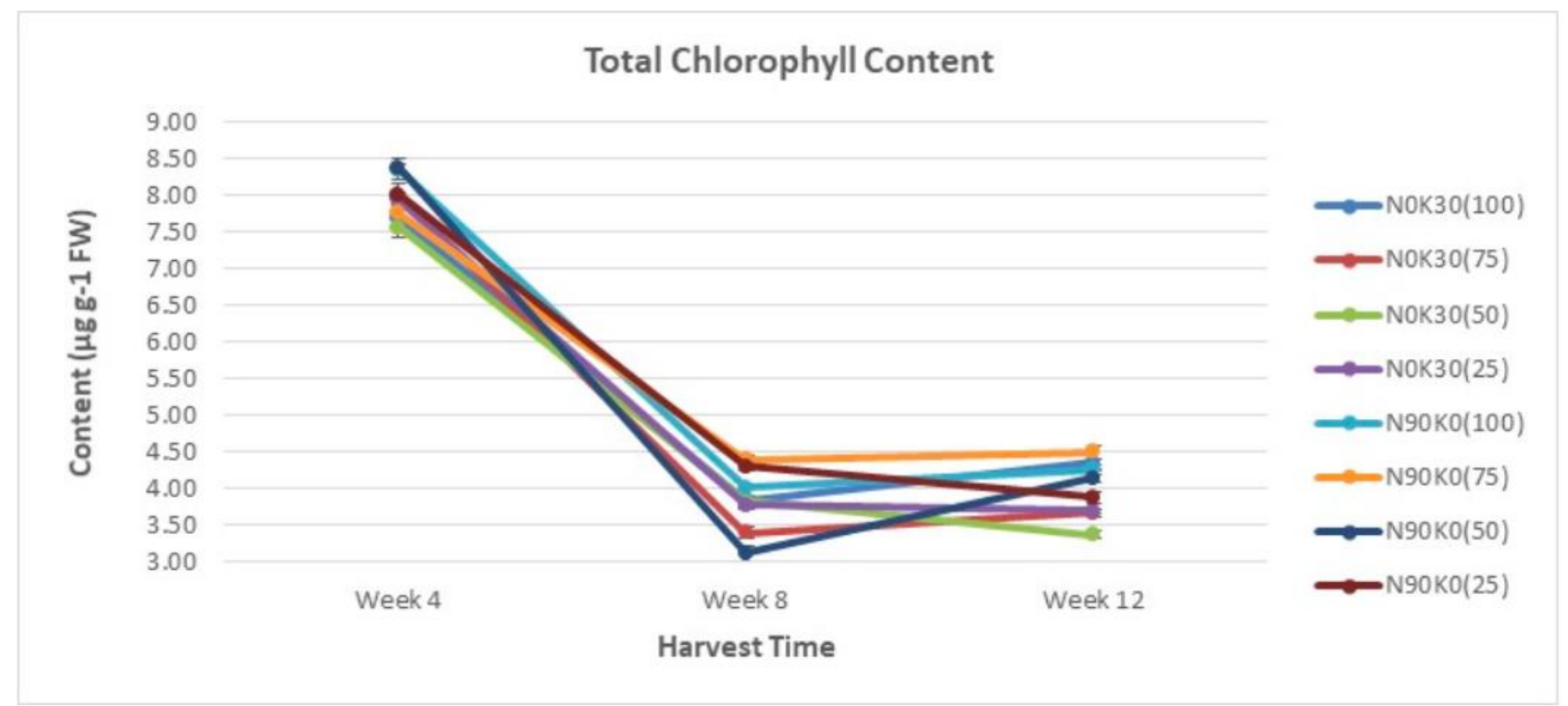

Figure 6. Changes in TChlC as affected by the interactions between rates of N, K and ER, and H time. Bars represents standard error of differences between the means $(\mathrm{p} \leq 0.05)$. $\mathrm{N}=72$. 


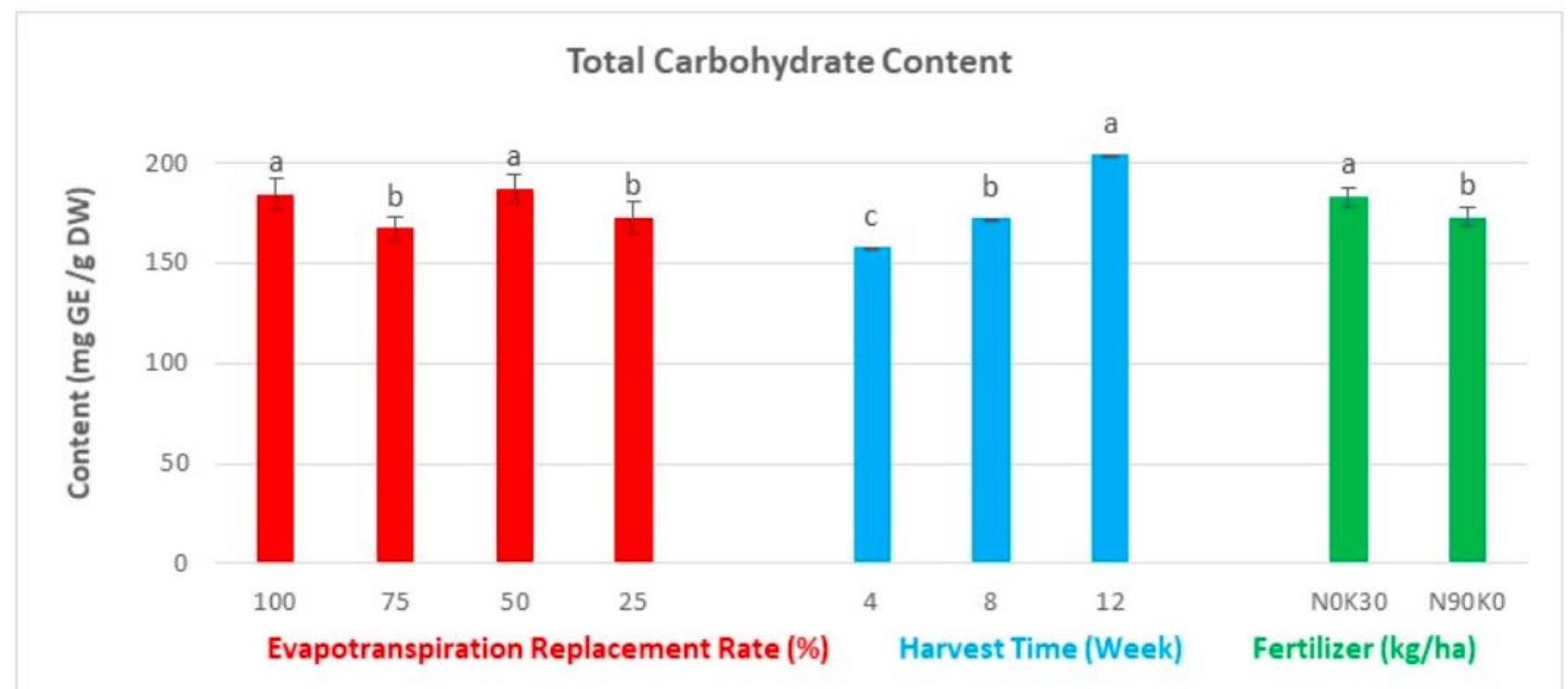

Figure 7. Effect of N, K and ER rates, and $\mathrm{H}$ time on TCC. Bars represents standard error of differences between the means. $N=72$. Different letters are means that are significantly different $(\mathrm{p} \leq 0.05)$. The calibration curves for the TCC markers (glucose) were linear over the range of 0.0 to $100.0 \mathrm{mg} / \mathrm{mL}$. The coefficient of determination $\left(\mathrm{R}^{2}\right)$ were greater than 0.995 for all standard curves.

Table 3. Effect of treatments and harvest time on biochemical assay variables.

\begin{tabular}{|c|c|c|c|c|c|c|}
\hline & TChlC & TCC & TPrC & TLiC & TPC & TFC \\
\hline \multicolumn{7}{|l|}{$\mathrm{NK}$} \\
\hline N0K30 & $5.10036^{\mathrm{b}}$ & $182.912^{a}$ & $26.3667^{a}$ & $20.750^{a}$ & $242.330^{\mathrm{a}}$ & $61.2039^{a}$ \\
\hline N90K0 & $5.40067 \mathrm{a}$ & $172.856^{\mathrm{b}}$ & $23.9453^{b}$ & $25.972^{a}$ & $228.309 a$ & $57.0561^{b}$ \\
\hline \multicolumn{7}{|l|}{ ER } \\
\hline 100 & $5.42556^{\mathrm{a}}$ & $184.548^{a}$ & $25.2528^{b}$ & $20.222^{b}$ & $238.37 \mathrm{a}$ & $61.116^{a}$ \\
\hline 75 & $5.22928^{b}$ & $167.331^{b}$ & $24.4800^{c}$ & $22.722^{b}$ & $239.06^{\mathrm{a}}$ & $61.157^{a}$ \\
\hline 50 & $5.07211^{c}$ & $186.898^{a}$ & $26.2978^{a}$ & $18.444^{b}$ & $241.03^{a}$ & $61.033^{a}$ \\
\hline 25 & $5.27511^{\mathrm{b}}$ & $172.759 \mathrm{~b}$ & $24.5933^{c}$ & $32.056^{a}$ & $222.81^{a}$ & $53.214^{\mathrm{b}}$ \\
\hline \multicolumn{7}{|l|}{$\mathrm{H}$} \\
\hline Week 4 & $7.96933^{\mathrm{a}}$ & $157.724^{c}$ & $20.2771^{c}$ & $19.208^{b}$ & $186.220^{c}$ & $51.616^{c}$ \\
\hline Week 8 & $3.79367 \mathrm{c}$ & $172.062^{\mathrm{b}}$ & $24.2454^{b}$ & $22.875^{\mathrm{ab}}$ & $215.884^{b}$ & $60.473^{b}$ \\
\hline Week 12 & $3.98854^{\mathrm{b}}$ & $203.866^{\mathrm{a}}$ & $30.9454^{a}$ & $28.000^{\mathrm{a}}$ & $303.853^{\mathrm{a}}$ & $65.301^{a}$ \\
\hline \multicolumn{7}{|l|}{ Interaction } \\
\hline $\mathrm{NK}$ & $<.0001 * * * *$ & $0.018^{*}$ & $<.0001 * * * *$ & $0.056^{\mathrm{ns}}$ & $0.087^{\mathrm{ns}}$ & $0.0001 * * *$ \\
\hline ER & $<.0001 * * * *$ & $0.003^{* *}$ & $<.0001 * * * *$ & $0.004 * *$ & $0.358^{\mathrm{ns}}$ & $<.0001 * * * *$ \\
\hline $\mathrm{H}$ & $<.0001 * * * *$ & $<.0001 * * * *$ & $<.0001 * * * *$ & $0.033^{*}$ & $<.0001 * * * *$ & $<.0001 * * * *$ \\
\hline NKxER & $0.354^{\mathrm{ns}}$ & $0.064^{\mathrm{ns}}$ & $<.0001 * * * *$ & $0.001 * *$ & $0.044^{*}$ & $<.0001 * * * *$ \\
\hline $\mathrm{NKxH}$ & $0.007 * *$ & $0.067 \mathrm{~ns}$ & $<.0001 * * * *$ & $0.105^{\mathrm{ns}}$ & $<.0001 * * * *$ & $<.0001 * * * *$ \\
\hline ERxH & $<.0001 * * * *$ & $0.022 *$ & $<.0001 * * * *$ & $0.281^{\mathrm{ns}}$ & $<.0001 * * * *$ & $<.0001 * * * *$ \\
\hline NKxERxH & $<.0001 * * * *$ & $0.363^{\mathrm{ns}}$ & $<.0001 * * * *$ & $0.122^{\mathrm{ns}}$ & $0.268^{\mathrm{ns}}$ & $<.0001 * * * *$ \\
\hline
\end{tabular}

All analyses are mean \pm SEM, $\mathrm{N}=216$ using DNMRT. $*$ significant at $\mathrm{p} \leq 0.05, * *$ significant at $\mathrm{p} \leq 0.01, * * *$ significant at $\mathrm{p} \leq 0.001, * * * *$ significant at $\mathrm{p} \leq 0.0001$, ns not significant at $\mathrm{p} \geq 0.05, \mathrm{~N}=$ Nitrogen, $\mathrm{K}=$ Potassium, ER=Evapotranspiration Replacement, $\mathrm{H}=$ Harvest Time, TChlC=Total Chlorophyll Content, TCC $=$ Total Carbohydrate Content, TPrC=Total Protein Content, TLiC=Total Lipid Content, TPC $=$ Total Phenolic Content, and TFC=Total Flavonoid Content.

\section{Total protein content}

The TPrC was affected by N, K and ER rates, and $\mathrm{H}$ time and statistically significant in all treatments with increasing harvesting time $(\mathrm{p} \leq 0.05)$ (Tables 1 and 3, and Figure 8). The 50 (\% ER) in N0K30 treatment $(0 \mathrm{~kg} \mathrm{~N} / \mathrm{ha}$ and $30 \mathrm{~kg} \mathrm{~K} / \mathrm{ha})$ and $25(\%$ $\mathrm{ER})$ in N90K0 (90 kg N/ha and $0 \mathrm{~kg} \mathrm{~K} / \mathrm{ha}$ ) have shown the highest TPrC, meanwhile, 25 (\% ER) in N0K30 and N90K0 have shown the lowest TPrC. The TPrC was highest under 50 (\% ER) in 
N0K30 at Week 12 compared to 25 (\% ER) in N90K0 at Week 4. The TPrC was constantly increased with rising harvesting time in both treatments (Figure 8). The measurements of TPrC were significantly correlated with Photo, TCC, TPC and TFC at $\mathrm{r}=-0.357 ; \mathrm{p} \leq 0.01, \mathrm{r}=0.745$; $\mathrm{p} \leq 0.0001, \quad \mathrm{r}=0.761 ; \mathrm{p} \leq 0.0001$ and $\mathrm{r}=0.300$; $\mathrm{p} \leq 0.05$, respectively. However, not significantly correlated with TLiC at $\mathrm{r}=0.131 ; \mathrm{p} \geq 0.05$ by a linear function (Tables 4 and 5). The event was probably because of physiologically, concentration of proline (proteinogenic amino acid in biosynthesis of proteins) was varied in plants due to different moisture conditions and nutritional status (Mohd Zain \& Ismail, 2016).
Drought stress will also increase organic compounds which are required for osmotic adjustment, such as proline (Mohd Zain \& Ismail, 2016; Mohd Zain et al., 2014; Rahimi et al., 2013). TPrC was high at Week 12 compared to Week 4 in both treatments, especially in 25\% ER (N90K0) (Figure 8). In addition, $\mathrm{K}$ also regulates solute transport, protein synthesis and enzyme activation which are related to plant metabolism (Armengaud et al., 2009; Armstrong, 1998). K increased plant's drought resistance through its functions in protein synthesis when $\operatorname{TPrC}$ was generally high under NOK30 (17-34 mg BSAE/g DW) compared to N90K0 treatments (16-32 mg BSAE/g DW) (Figure 8).

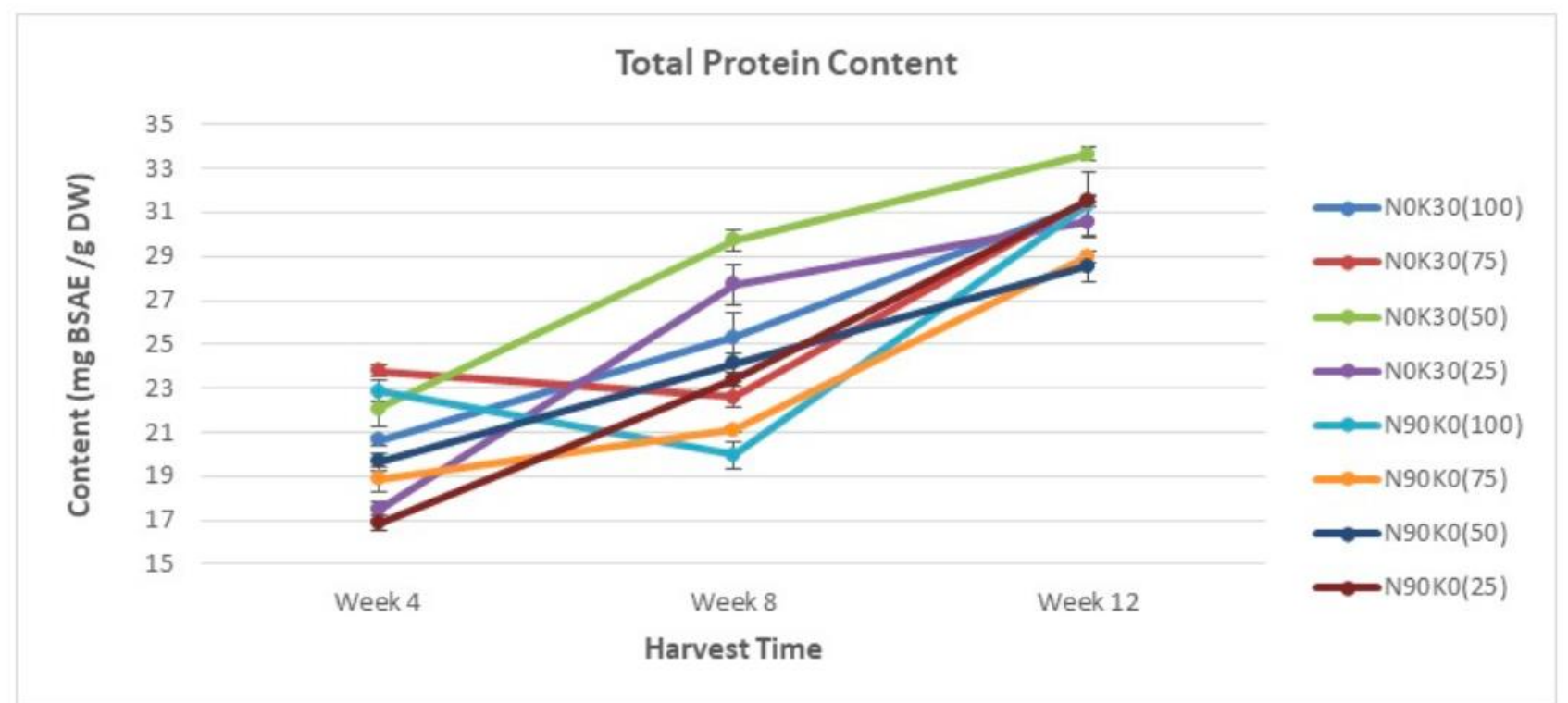

Figure 8. Changes in TPrC as affected by the interactions between rates of N, K and ER, and $H$ time. Bars represents standard error of differences between the means $(\mathrm{p} \leq 0.05) . \mathrm{N}=72$. The calibration curves for the TPrC markers (bovine serum albumin) were linear over the range of 0.0 to $1.0 \mathrm{mg} / \mathrm{mL}$. The coefficient of determination $\left(\mathrm{R}^{2}\right)$ were greater than 0.990 for all standard curves.

\section{Total lipid content}

The TLiC was affected by ER rates and $\mathrm{H}$ time and statistically not significant in all $\mathrm{N}$ and $\mathrm{K}$ treatments, increased with increasing harvesting time and significantly different $(\mathrm{p} \leq 0.05)$ with decreasing ER rate including the control plants (Tables 1 and 3, and Figure 9). The TLiC was highest in $25 \%$ ER at Week 12 compared to the lowest in 50\% ER at Week 4. The TLiC was increased with rising harvesting time, slightly constant in both $\mathrm{N}$ and $\mathrm{K}$ interaction treatments, and fluctuate in all ER treatments (Figure 9). However, the measurements of TLiC were not significantly correlated with Photo, TCC, TPrC,
TPC and TFC at $\mathrm{r}=-0.046 ; \mathrm{p} \geq 0.05, \mathrm{r}=0.218$; $\mathrm{p} \geq 0.05, \mathrm{r}=0.131 ; \mathrm{p} \geq 0.05, \mathrm{r}=0.120 ; \mathrm{p} \geq 0.05$ and $\mathrm{r}=0.117 ; \mathrm{p} \geq 0.05$, respectively by a linear function (Tables 4 and 5). The event was probably because of physiologically, when water stress rates have increased, the oxidative stress in plant cells and tissues will be enhanced, causing lipid peroxidation under high water stress (Jaafar et al., 2012), $20.222 \mathrm{mg} / \mathrm{g}$ DW (100\% ER), 22.722 $\mathrm{mg} / \mathrm{g}$ DW (75\% ER), $18.444 \mathrm{mg} / \mathrm{g}$ DW $(50 \%$ ER), and $32.056 \mathrm{mg} / \mathrm{g} \mathrm{DW}$ (25\% ER) (Figure 9). The formation of malondialdehyde was measured as lipid peroxidation which was induced by high 
water stress level (Jaafar et al., 2012; Mohd Zain et al., 2014b).

\section{Total phenolic content}

The TPC was affected by $\mathrm{H}$ time and statistically consistent in all $\mathrm{N}$ and $\mathrm{K}$ treatments, increased with increasing harvesting time and no significant difference $(\mathrm{p} \leq 0.05)$ with decreasing ER rate including the control plants (Tables 1 and 3, and Figure 10). The TPC was highest at Week 12 compared to Week 4. The interaction treatment was statistically not significant $(\mathrm{p} \leq 0.05)$, but the harvest time was significantly different $(\mathrm{p} \leq 0.05)$ (Figure 10). However, the measurements of TPC were significantly correlated with TCC and TPrC at $\mathrm{r}=0.515 ; \mathrm{p} \leq 0.0001$ and $\mathrm{r}=0.761 ; \mathrm{p} \leq 0.0001$, respectively. However, not significantly correlated with Photo, TLiC and TFC at $\mathrm{r}=-0.121 ; \mathrm{p} \geq 0.05$, $\mathrm{r}=0.120 ; \quad \mathrm{p} \geq 0.05$ and $\mathrm{r}=0.188 ; \quad \mathrm{p} \geq 0.05$, respectively by a linear function (Tables 4 and 5). The event was probably because of constant ratio of $\mathrm{N}$ limitation to carbon allocation for plant growth where $\mathrm{N}$ deficiency has increases phenolic concentrations in the plants (Caretto et al., 2015; Larbat et al., 2012; Le Bot et al., 2009). The result was in accordance with the report when TPC was slightly high in $\mathrm{N} 0$ at Week 12 compared to N90
(Figure 10). The concentration of phenolics increases in plant tissues was either as existing pools or by inducing their de novo synthesis (Romagni, 2009). In addition, the accumulation of TCC has provides a signal for secondary metabolites production in the plants. However, less significant accumulation of TCC in this study was correlated to non-significant production of TPC corresponded.

\section{Quantification of phenolics Thin layer chromatography}

Qualitative analysis of methanol extract was performed using a mixture of toluene: ethyl acetate: formic acid $(5: 4: 1 \mathrm{v} / \mathrm{v})$ as the mobile phase (Sasidharan et al., 2011) yielded a good resolution of caffeic acid and ferulic acid with bands at $\mathrm{R}_{\mathrm{f}}=0.64$ and 0.69 , respectively. Caffeic acid and ferulic acid were identified and quantified at visible light, 254 and $366 \mathrm{~nm}$ (Figure 11). The result has revealed that the methanol extract at 1 $\mathrm{g} / 10 \mathrm{~mL}$ of $100 \%$ methanol contained caffeic acid and ferulic acid in accordance to the TPC analysis (highest under N90K0(75) treatments at Week 12 compared to N90K0(75) at Week 8. (Figure 10).

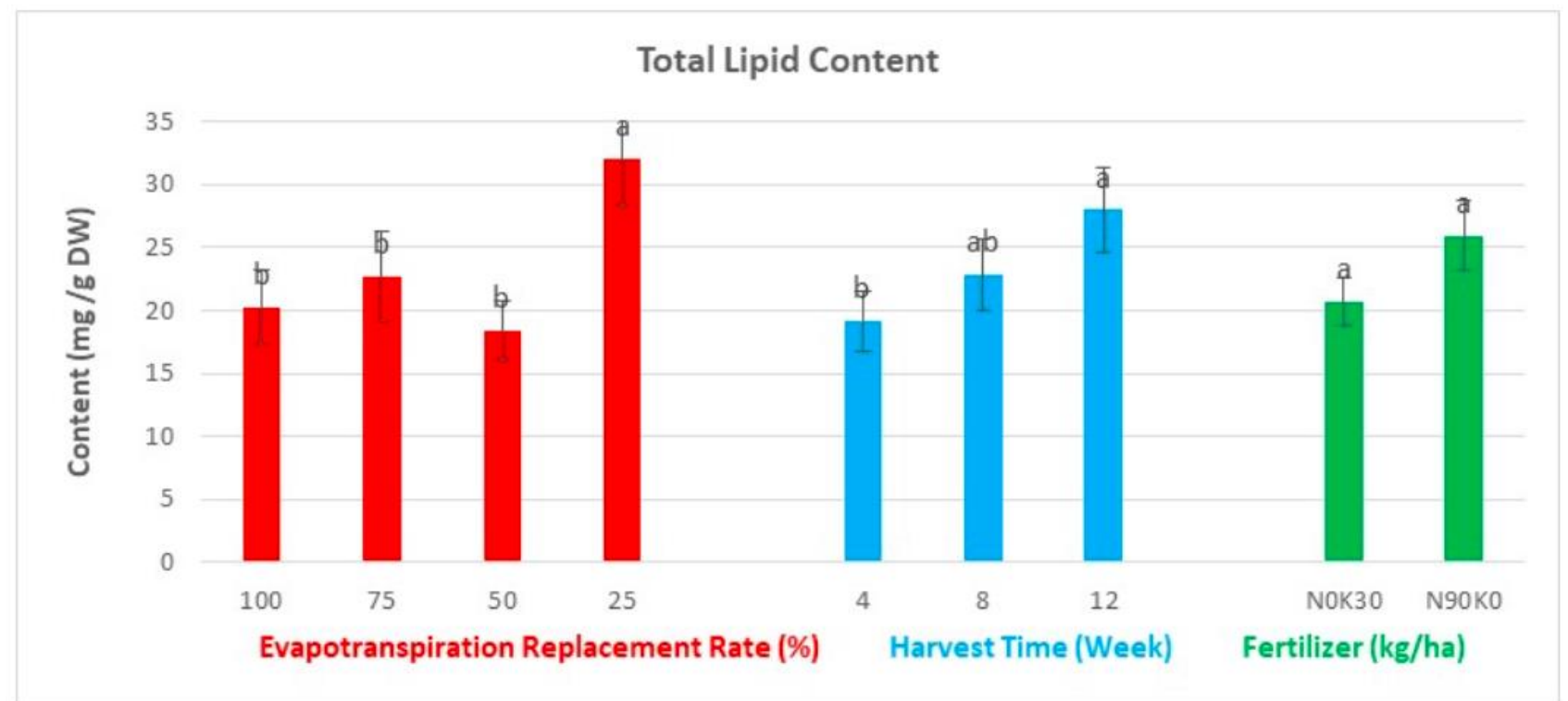

Figure 9. Effect of N, K and ER rates, and $\mathrm{H}$ time on TLiC. Bars represents standard error of differences between the means. $N=72$. Different letters are means that are significantly different $(p \leq 0.05)$. 


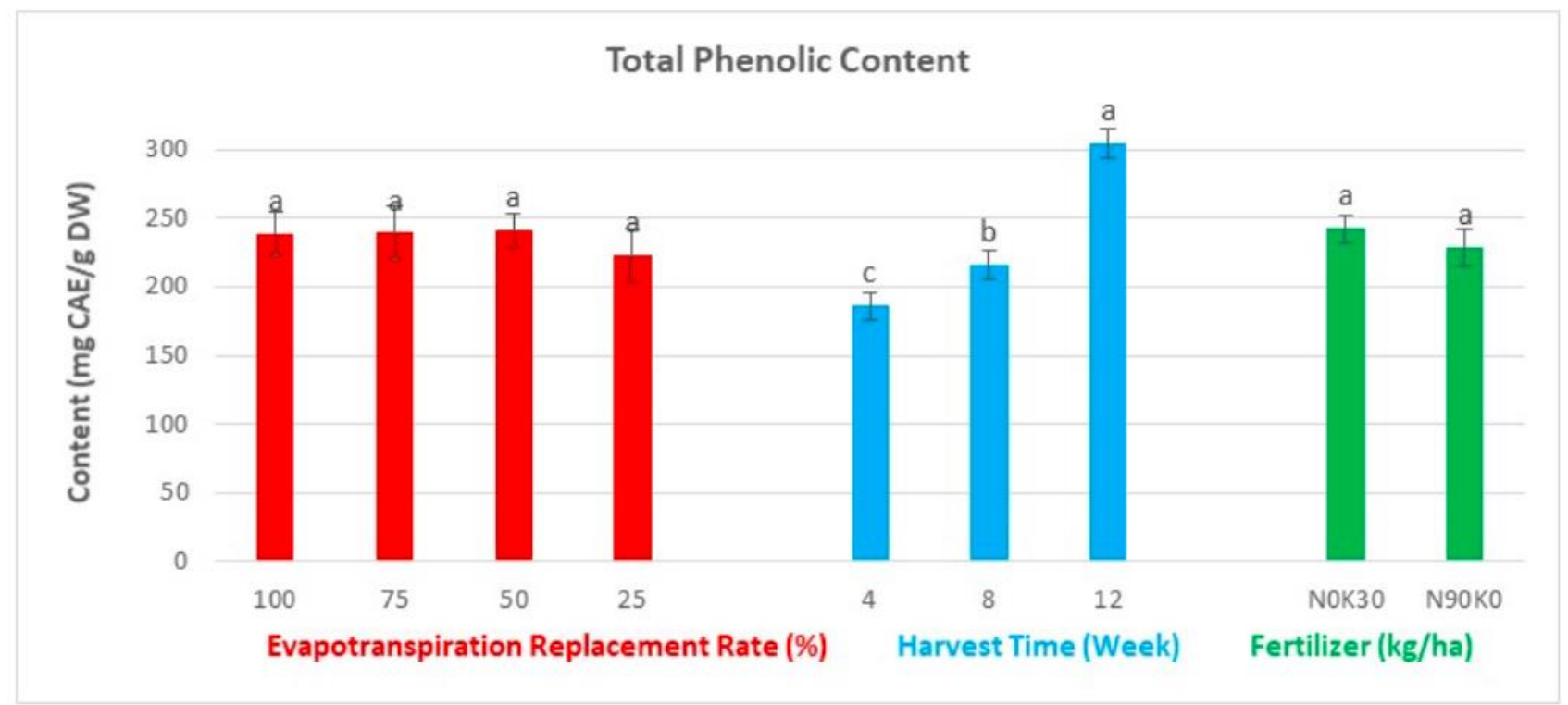

Figure 10. Effect of N, K and ER rates, and $\mathrm{H}$ time on TPC. Bars represents standard error of differences between the means. $N=72$. Different letters are means that are significantly different $(p \leq 0.05)$. The calibration curves for the TPC compounds markers (caffeic acid) were linear over the range of 0.1 to 2.0 $\mathrm{mg} / \mathrm{mL}$. The coefficient of determination $\left(\mathrm{R}^{2}\right)$ were greater than 0.994 for all standard curves.
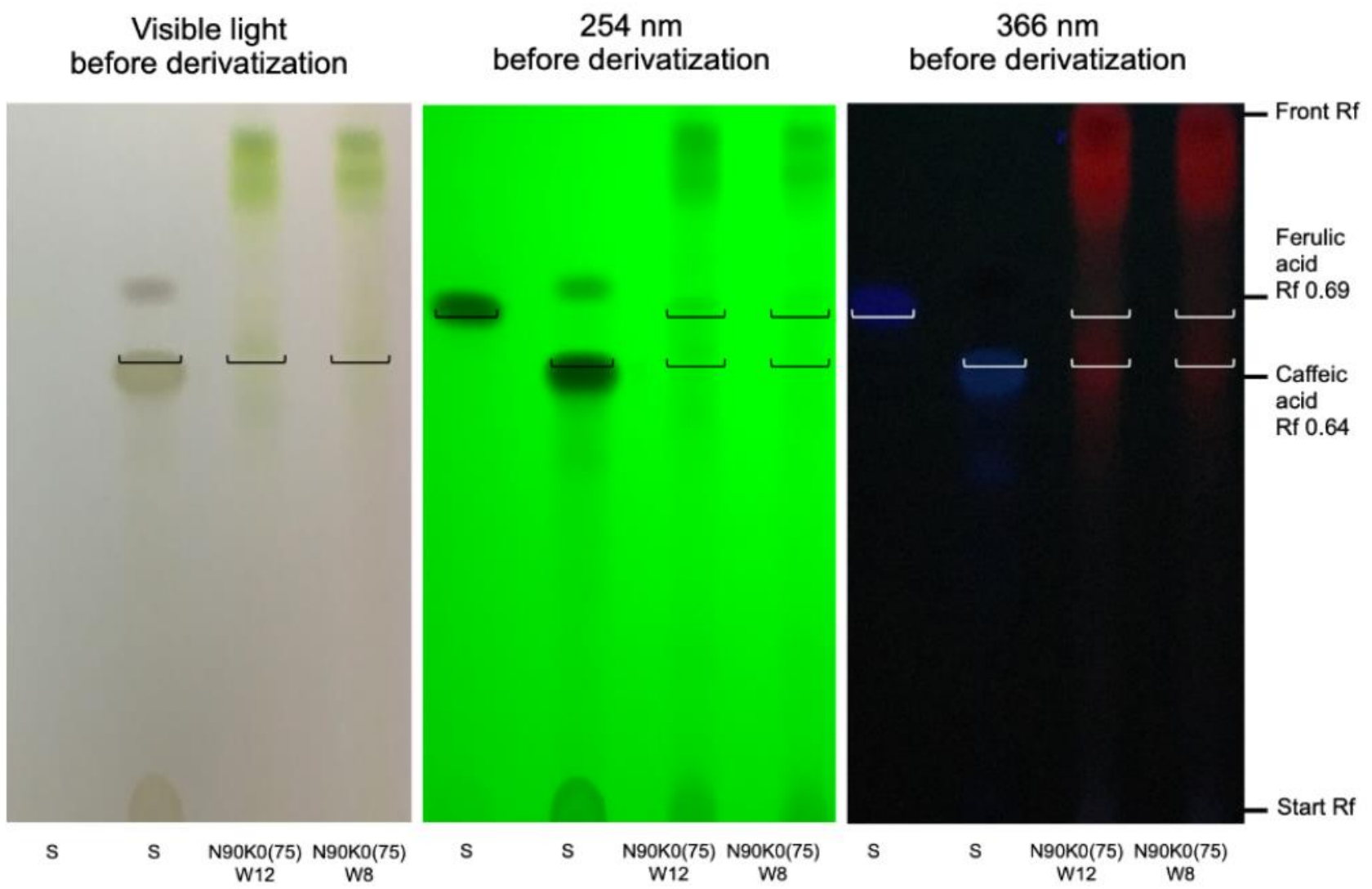

Figure 11. Thin layer chromatography profiles of caffeic acid (S) and ferulic acid (S), methanol extract of dried leaves powder observed under various wavelength. 


\section{High-performance liquid chromatography}

Quantitative analysis of methanol extract was performed using a mixture of $0.1 \%$ of $85 \%$ orthophosphoric acid: acetonitrile (90.5:9.5, v/v isocratically) (Kaewseejan \& Siriamornpun, 2015; Olkowski et al., 2003; Rivai et al., 2011) as the eluent yielded a good peak of caffeic acid at $t_{r}=6.3-6.4 \mathrm{~min}, 327 \mathrm{~nm}$ (Figure 12). The results revealed that the methanol extract at $1 \mathrm{~g} / 10 \mathrm{~mL}$ of $100 \%$ methanol contained caffeic acid in accordance to the TPC analysis (highest under N90K0(75) treatments at Week 12, peak 5, $t_{r}=6.459 \mathrm{~min}, 67.57 \%$ Area compared to $\mathrm{N} 90 \mathrm{~K} 0(75)$ at Week 8 , peak $5, t_{r}=6.333 \mathrm{~min}$, $37.56 \%$ Area) (Figure 10).
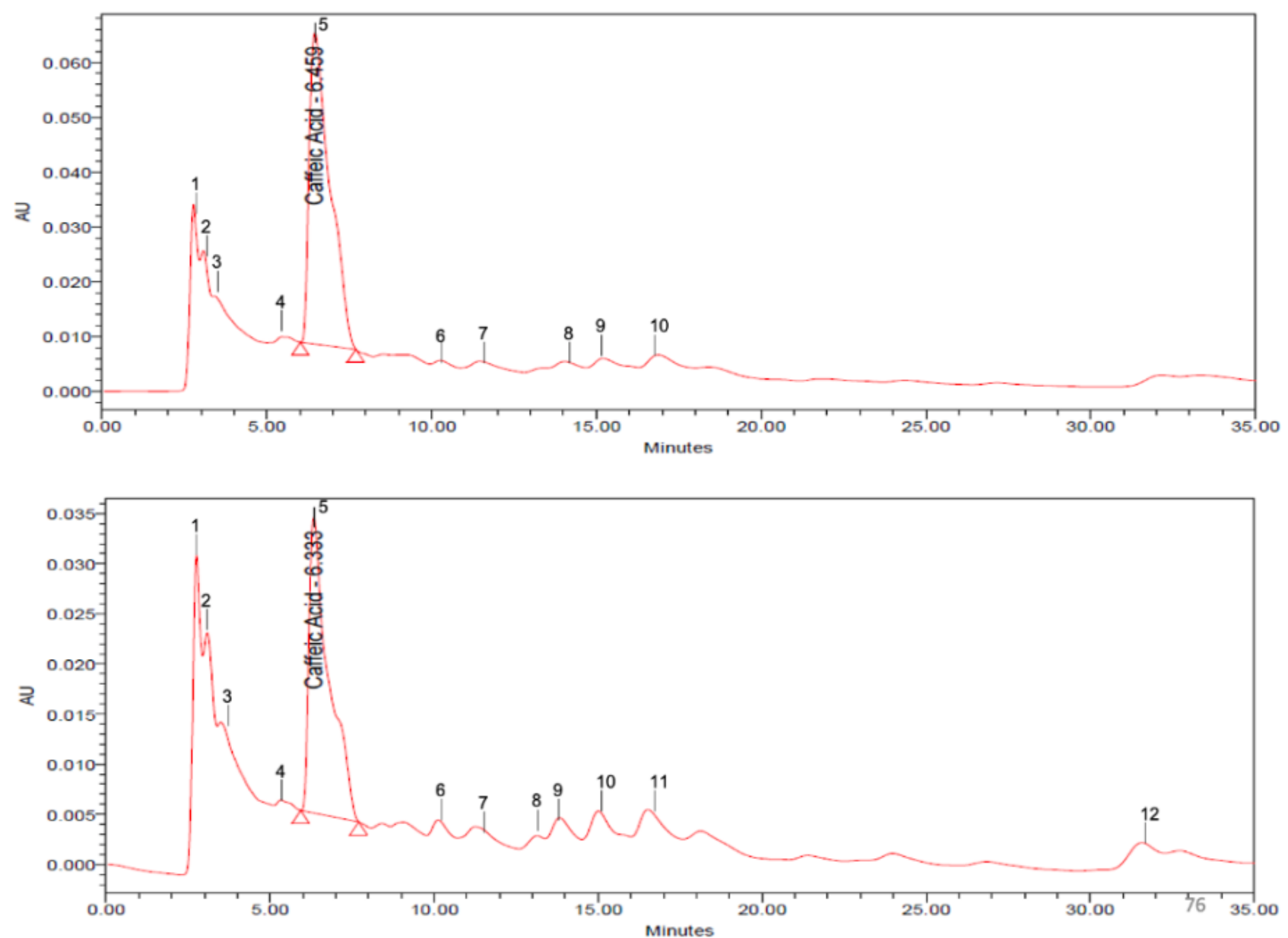

Figure 12. High-performance liquid chromatogram profiles of caffeic acid standard solution $(1.0 \mathrm{mg} / \mathrm{mL})$ at $t_{r}=6.3-6.4 \mathrm{~min}$, methanol extract of $G$. procumbens dried leaves powder (a) N90K0(75) Week 12 and (b) N90K0(75) Week 8 observed under $327 \mathrm{~nm}$ derivatization. The calibration curves for the TPC markers (caffeic acid) were linear over the range of 0.05 to $0.17 \mathrm{mg} / \mathrm{mL}$. The coefficient of determination $\left(\mathrm{R}^{2}\right)$ were greater than 0.999 for all standard curves.

\section{Total flavonoid content}

The TFC was affected by N, K and ER rates, and $\mathrm{H}$ time, and statistically significant in all treatments with increasing harvesting time $(p \leq 0.05)$ (Tables 1 and 3, and Figure 13). The 75 $(\%$ ER) in N0K30 treatment $(0 \mathrm{~kg} \mathrm{~N} / \mathrm{ha}$ and 30 $\mathrm{kg} \mathrm{K} / \mathrm{ha})$ and 50 (\% ER) in N90K0 (90 kg N/ha and $0 \mathrm{~kg} \mathrm{~K} / \mathrm{ha}$ ) have shown the highest TFC, meanwhile, 25 (\% ER) in N0K30 and 75 (\% ER) in N90K0 have shown the lowest TFC. The TFC was highest under 50 (\% ER) in N90K0 at Week 12 compared to 75 (\% ER) in N90K0 at Week 4. The TFC was constantly increased with rising harvesting time in both treatments (Figure 13). The measurements of TFC were significantly correlated with Photo, TCC and TPrC at $\mathrm{r}=$ $0.365 ; \mathrm{p} \leq 0.01, \mathrm{r}=0.262 ; \mathrm{p} \leq 0.05$ and $\mathrm{r}=0.300$; $\mathrm{p} \leq 0.05$, respectively. However, not significantly correlated with TLiC and TPC at $\mathrm{r}=0.117$; $\mathrm{p} \geq 0.05$ and $\mathrm{r}=0.188 ; \mathrm{p} \geq 0.05$, respectively by a 
linear function (Tables 4 and 5). The event was probably due to resource-limited environments, where carbon partitioning to constitutive secondary metabolism has increases, which enhances resistance to pathogens attack as well as stress tolerance (Caretto et al., 2015). The accumulation of flavonoids has indicated the limitations of plant growth was correlated with higher secondary metabolite production (Marchese et al., 2010; Massad et al., 2011). Meanwhile, $\mathrm{N}$ deficiency has also induces accumulation of ascorbic acid, flavonoids, and flavonols (Ibrahim et al., 2013). The result was in accordance to the reports when TFC was high in N0 treatment (40-80 $\mathrm{mg} \mathrm{KE/g} \mathrm{DW)} \mathrm{compared}$ to N90 (20-80 mg KE/g DW) (Figure 13). The TFC has increased in low K treatment (N90K0), meanwhile, enough $\mathrm{K}$ concentration (N0K30) has maintained the flavonoids concentration (Chen et al., 2013). In addition, the increases of TFC (70 $\mathrm{mg} \mathrm{KE} / \mathrm{g} \mathrm{DW}$ and $83 \mathrm{mg} \mathrm{KE} / \mathrm{g} \mathrm{DW})$ under high water stress (50\% ER and 25\% ER) to TCC (Figure 7) was also due to reduced transportation of soluble sugar under water limitation (Kleczewski et al., 2010). On the other hands, low maximum quantum yield (0.01-0.49 $\mathrm{Fv} / \mathrm{Fm}$ ) (Figure 4) has caused the increases of secondary metabolites production, especially flavonoid under low water field capacity $(25 \%$ and $50 \%$ ER). The event was demonstrated the correlation of secondary metabolites production under increasing water stress condition (Ibrahim et al., 2017; Zoratti et al., 2014).

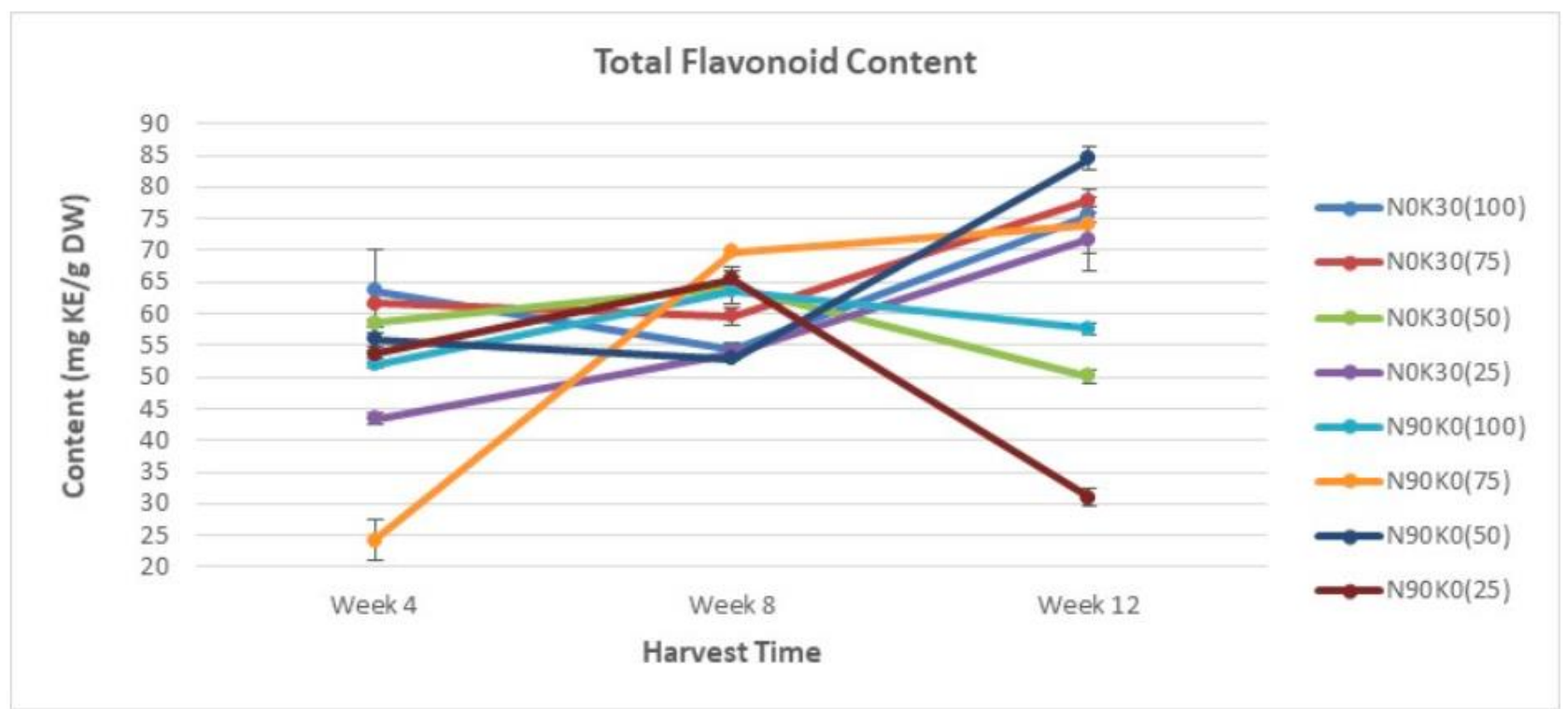

Figure 13. Changes in TFC as affected by the interactions between rates of N, K and ER, and $\mathrm{H}$ time. Bars represents standard error of differences between the means $(\mathrm{p} \leq 0.05)$. $\mathrm{N}=72$. The calibration curves for the TFC compounds markers (kaempferol) were linear over the range of 0.04 to $1.80 \mathrm{mg} / \mathrm{mL}$. The coefficient of determination $\left(\mathrm{R}^{2}\right)$ were greater than 0.993 for all standard curves. 

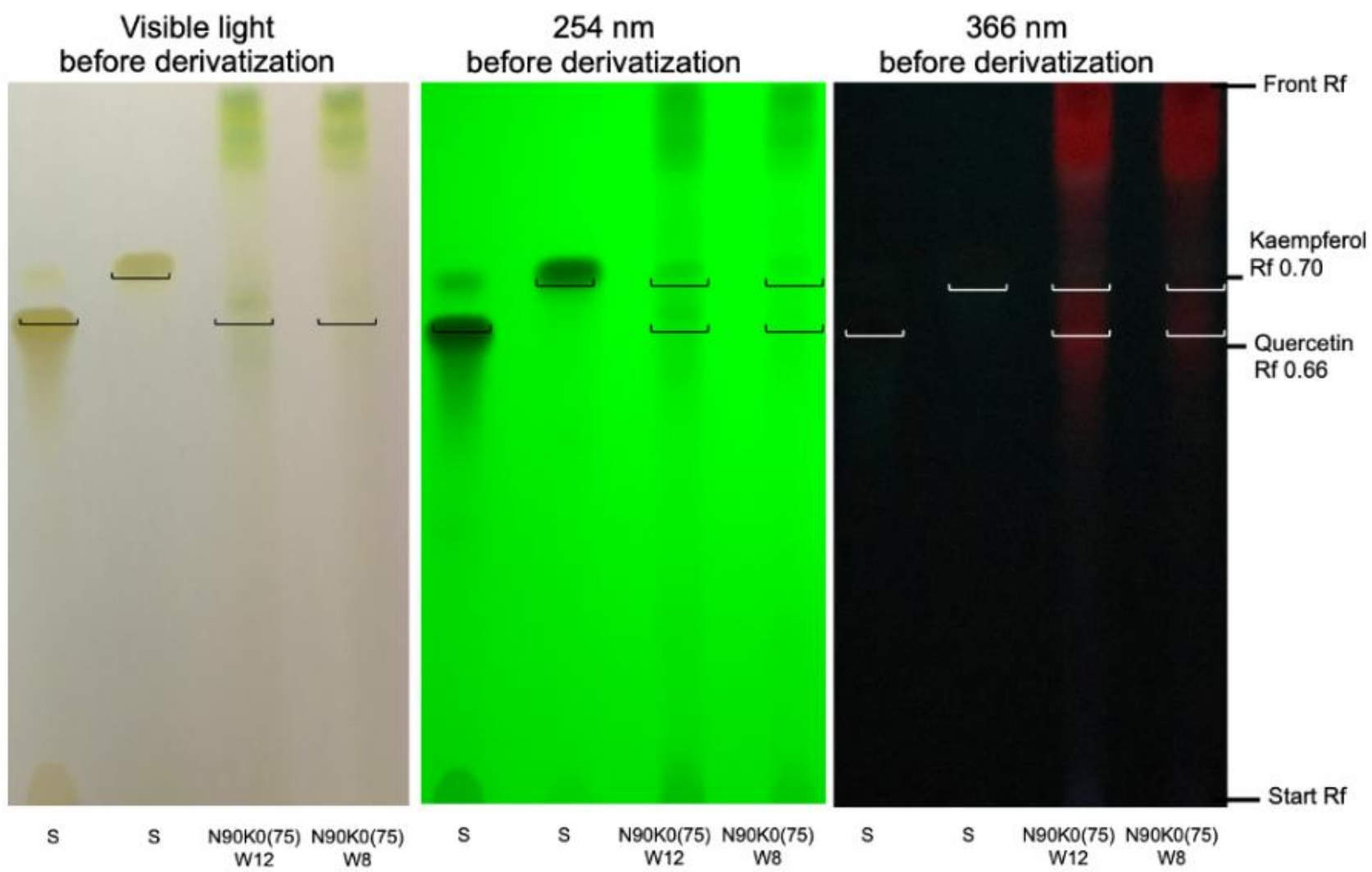

Figure 14. Thin layer chromatography developed-profiles of kaempferol (S), methanol extract of dried leaves powder observed under under various wavelength.

\section{Quantification of flavonoids Thin layer chromatography}

Qualitative analysis of methanol extract was performed using a mixture of toluene: ethyl acetate: formic acid $(5: 4: 1 \mathrm{v} / \mathrm{v})$ as the mobile phase (Sasidharan et al., 2011) yielded a good resolution of kaempferol with bands at $\mathrm{R}_{\mathrm{f}}=0.70$. Kaempferol were identified and quantified at visible light, 254 and $366 \mathrm{~nm}$ (Figure 14). The result has revealed that the methanol extract at 1 $\mathrm{g} / 10 \mathrm{~mL}$ of $100 \%$ methanol contained kaempferol in accordance to the TFC analysis (highest under N90K0(75) treatments at Week 12 compared to N90K0(75) at Week 8 (Figure 13).

\section{High-performance liquid chromatography}

Quantitative analysis of methanol extract was performed using a mixture of $0.03 \mathrm{M}$ of $85 \%$ orthophosphoric acid: methanol $(60: 40, \mathrm{v} / \mathrm{v}$ isocratically) (Olszewska, 2007; Yi et al., 2016a; Yu et al., 2010) as the eluent yielded a good peak of kaempferol at $t_{r}=10.9-11.0 \mathrm{~min}, 250$ to $360 \mathrm{~nm}$ (Figure 15). The results revealed the methanol extract at $1 \mathrm{~g} / 10 \mathrm{~mL}$ of $100 \%$ methanol contained kaempferol in accordance to the TFC analysis (highest under N90K0(75) treatments at Week 12, peak 7, $t_{r}=11.054 \mathrm{~min}, 6.06 \%$ Area compared to the N90K0(75) at Week 6, peak 2, $t_{r}=10.923 \mathrm{~min}$, $0.21 \%$ Area) (Figure 13).

\section{DISCUSSION}

Generally, the study reported the effects of N, K and ER treatments interaction on growth and phytochemical content (primary and secondary metabolites) of $G$. procumbens. Fertilizer or nutrient supply $(\mathrm{N}$ and $\mathrm{K})$ and water stress (ER) are among the significant abiotic stress affecting plant growth because plants react to the stresses through morphological and physiological changes (Kennelly et al., 2012; Li, 2002; Ramakrishna \& Ravishankar, 2011; Schutzki \& Cregg, 2007; Szakiel et al., 2011). Adverse growing conditions will certainly exhibit direct effect on growth, physiology and phytochemical production mechanisms (Michalak, 2006).

Theoretically, water deficit or surplus will induce stress-related metabolic responses. For 
example, in low Cond, the uptake of $\mathrm{CO}_{2}$ decreases significantly (Marchese et al., 2010; Yadav et al., 2014). Thus, the consumption of reduction equivalents $\left(\mathrm{NADPH}^{+} \mathrm{H}^{+}\right)$for $\mathrm{CO}_{2}$ fixation via Calvin cycle declines accordingly, generating large oxidative stress and over-supply of reduction equivalents (Selmar \& Kleinwächter, 2013). Consequently, metabolic processes shifted towards biosynthetic activities which consume reduction equivalents. Subsequently, the synthesis of reduced compounds, such as phenols, is enhanced (de Matos et al., 2014; Shoeva et al., 2016). Since the stress-related metabolic changes effecting the plant processes extensively, the synthesis and accumulation of secondary metabolites will be affected as well (de Matos et al., 2014; Ren et al., 2014).
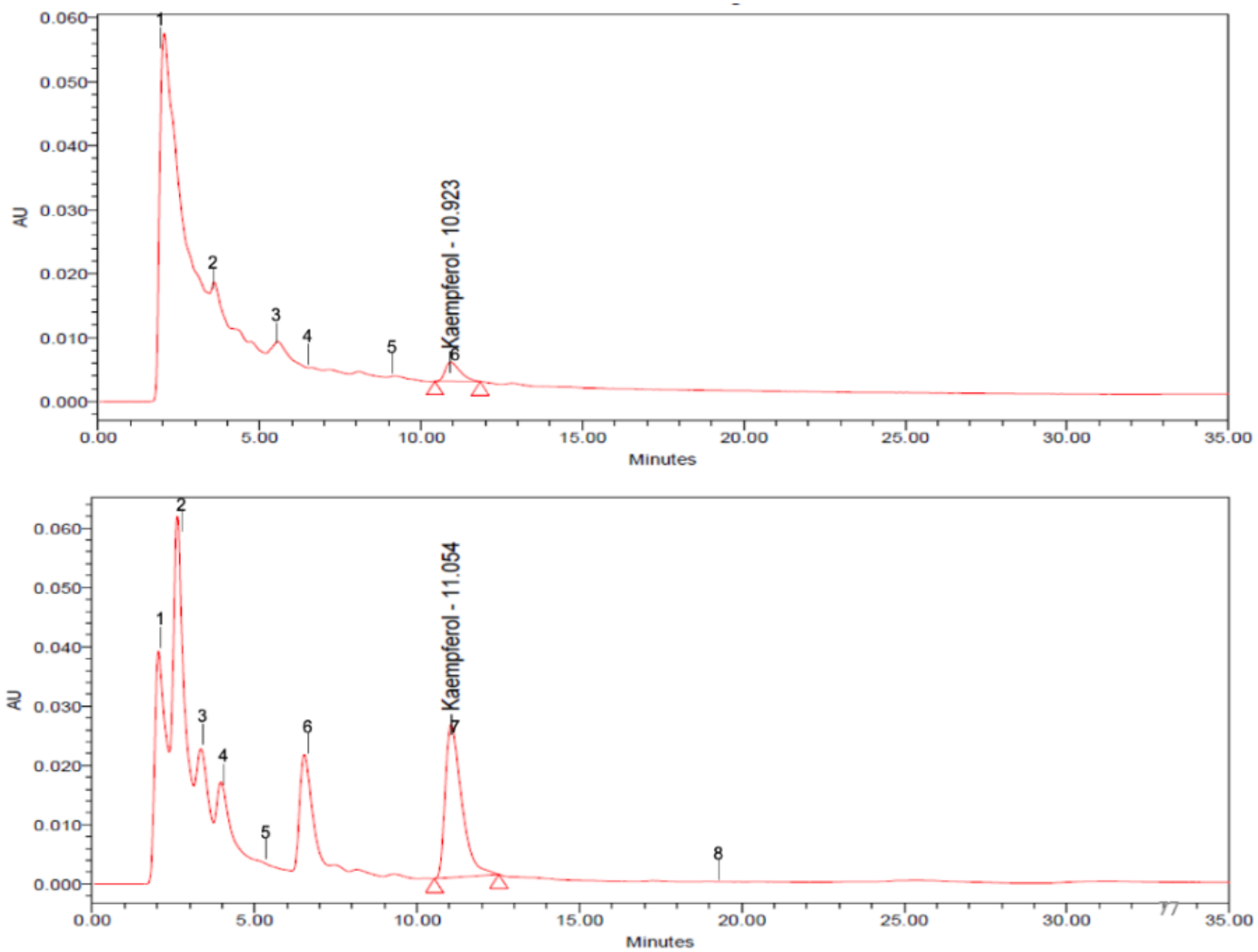

Figure 15. High-performance liquid chromatogram profiles of kaempferol standard solution $(1.0 \mathrm{mg} / \mathrm{mL})$ at $t_{r}=10.9-11.0 \mathrm{~min}$, methanol extract of $G$. procumbens dried leaves powder (a) N90K0(75) Week 12 and (b) N90K0(75) Week 8 observed under 250 to $360 \mathrm{~nm}$ derivatization. The calibration curves for the TFC compounds markers (kaempferol) were linear over the range of 0.2 to $0.6 \mathrm{mg} / \mathrm{mL}$. The coefficient of determination $\left(\mathrm{R}^{2}\right)$ were greater than 0.999 for all standard curves. 
Table 4. Correlation of growth and physiology variables.

\begin{tabular}{|c|c|c|c|c|c|c|c|c|c|c|c|c|c|c|}
\hline & $\mathbf{H}$ & TPDW & NoL & TLA & Photo & Cond & CF & PWP & TChlC & TCC & TPrC & TLiC & TPC & TFC \\
\hline I & 1.000 & & & & & & & & & & & & & \\
\hline$\stackrel{8}{\mathrm{Q}}$ & $\begin{array}{l}0.811 \\
* * * *\end{array}$ & 1.000 & & & & & & & & & & & & \\
\hline ڤ & $\begin{array}{l}0.573 \\
* * * *\end{array}$ & $\begin{array}{c}0.296 \\
*\end{array}$ & 1.000 & & & & & & & & & & & \\
\hline$\underset{H}{\&}$ & $\begin{array}{c}0.761 \\
* * * *\end{array}$ & $\begin{array}{l}0.520 \\
* * * *\end{array}$ & $\begin{array}{c}0.833 \\
* * * *\end{array}$ & 1.000 & & & & & & & & & & \\
\hline$\frac{0}{\stackrel{2}{2}}$ & $\begin{array}{c}-0.430 \\
* * *\end{array}$ & $\begin{array}{l}-0.282 \\
*\end{array}$ & $\begin{array}{c}-0.519 \\
* * * *\end{array}$ & $\begin{array}{c}-0.510 \\
* * * *\end{array}$ & 1.000 & & & & $\begin{array}{l}0.556 \\
* * * *\end{array}$ & $\begin{array}{c}-0.360 \\
* *\end{array}$ & $\begin{array}{c}-0.357 \\
* *\end{array}$ & $\begin{array}{c}-0.046 \\
\mathrm{~ns}\end{array}$ & $\begin{array}{c}-0.121 \\
\mathrm{~ns}\end{array}$ & $\begin{array}{c}-0.365 \\
* *\end{array}$ \\
\hline ن̊. & $\begin{array}{l}0.729 \\
* * * *\end{array}$ & $\begin{array}{l}0.590 \\
* * * *\end{array}$ & $\begin{array}{c}0.208 \\
\text { ns }\end{array}$ & $\begin{array}{c}0.418 \\
* * *\end{array}$ & $\begin{array}{c}-0.037 \\
\text { ns }\end{array}$ & 1.000 & & & & & & & & \\
\hline 甹 & $\begin{array}{c}-0.070 \\
\mathrm{~ns}\end{array}$ & $\begin{array}{c}-0.087 \\
\text { ns }\end{array}$ & $\begin{array}{c}0.068 \\
\mathrm{~ns}\end{array}$ & $\begin{array}{c}0.0001 \\
\text { ns }\end{array}$ & $\begin{array}{c}-0.0002 \\
\text { ns }\end{array}$ & $\begin{array}{c}-0.048 \\
\text { ns }\end{array}$ & 1.000 & & $\begin{array}{c}0.034 \\
\text { ns }\end{array}$ & $\begin{array}{c}-0.062 \\
\text { ns }\end{array}$ & $\begin{array}{c}-0.095 \\
\text { ns }\end{array}$ & $\begin{array}{c}-0.230 \\
\mathrm{~ns}\end{array}$ & $\begin{array}{c}0.074 \\
\text { ns }\end{array}$ & $\begin{array}{c}0.105 \\
\text { ns }\end{array}$ \\
\hline 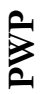 & $\begin{array}{c}0.139 \\
\text { ns }\end{array}$ & $\begin{array}{l}0.232 \\
*\end{array}$ & $\begin{array}{c}-0.115 \\
\text { ns }\end{array}$ & $\begin{array}{c}-0.035 \\
\mathrm{~ns}\end{array}$ & $\begin{array}{c}0.190 \\
\text { ns }\end{array}$ & $\begin{array}{c}0.169 \\
\text { ns }\end{array}$ & $\begin{array}{l}-0.419 \\
* * *\end{array}$ & 1.000 & & & & & & \\
\hline
\end{tabular}

All analyses are mean \pm SEM, $\mathrm{N}=216$ using DNMRT. $*$ significant at $\mathrm{p} \leq 0.05, * *$ significant at $\mathrm{p} \leq 0.01, * * *$ significant at $\mathrm{p} \leq 0.001, * * * *$ significant at $\mathrm{p} \leq 0.0001$, and ns not significant at $\mathrm{p} \geq 0.05, \mathrm{H}=$ Harvest Time, TPDW $=$ Total Plant Dry Weight, NoL=Number of Leaves, TLA=Total Leaf Area, Photo=Photosynthetic Rate, Cond=Stomatal Conductance Rate, $\mathrm{CF}=$ Chlorophyll Fluorescence Rate, PWP=Plant Water Potential Rate, TChlC=Total Chlorophyll Content, TCC=Total Carbohydrate Content, TPrC=Total Protein Content, TLiC=Total Lipid Content, TPC=Total Phenolic Content, and TFC=Total Flavonoid Content. 
Table 5. Correlation of biochemical assay variables.

\begin{tabular}{|c|c|c|c|c|c|c|c|}
\hline & $\mathbf{H}$ & TChlC & TCC & TPrC & TLiC & TPC & TFC \\
\hline U્ & $\begin{array}{c}-0.831 \\
* * * *\end{array}$ & 1.000 & & & & & \\
\hline U & $\begin{array}{l}0.634 \\
* * * *\end{array}$ & $\begin{array}{l}-0.465 \\
* * * *\end{array}$ & 1.000 & & & & \\
\hline Un & $\begin{array}{l}0.857 \\
* * * *\end{array}$ & $\begin{array}{l}-0.663 \\
* * * *\end{array}$ & $\begin{array}{l}0.745 \\
* * * *\end{array}$ & 1.000 & & & \\
\hline 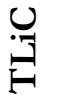 & $\begin{array}{c}0.252 \\
*\end{array}$ & $\begin{array}{c}-0.158 \\
\text { ns }\end{array}$ & $\begin{array}{c}0.218 \\
\text { ns }\end{array}$ & $\begin{array}{c}0.131 \\
\text { ns }\end{array}$ & 1.000 & & \\
\hline $\begin{array}{l}\text { U } \\
\text { H }\end{array}$ & $\begin{array}{l}0.685 \\
* * * *\end{array}$ & $\begin{array}{l}-0.455 \\
* * * *\end{array}$ & $\begin{array}{l}0.515 \\
* * * *\end{array}$ & $\begin{array}{l}0.761 \\
* * * *\end{array}$ & $\begin{array}{c}0.120 \\
\text { ns }\end{array}$ & 1.000 & \\
\hline U & $\begin{array}{c}0.401 \\
* * *\end{array}$ & $\begin{array}{c}-0.327 \\
* *\end{array}$ & $\begin{array}{c}0.262 \\
*\end{array}$ & $\begin{array}{c}0.300 \\
*\end{array}$ & $\begin{array}{c}0.117 \\
\mathrm{~ns}\end{array}$ & $\begin{array}{c}0.188 \\
\text { ns }\end{array}$ & 1.000 \\
\hline
\end{tabular}

All analyses are mean \pm SEM, $\mathrm{N}=216$ using DNMRT. $*$ significant at $\mathrm{p} \leq 0.05, * *$ significant at $\mathrm{p} \leq 0.01, * * *$ significant at $\mathrm{p} \leq 0.001$, **** significant at $\mathrm{p} \leq 0.0001$, and ns not significant at $\mathrm{p} \geq 0.05, \mathrm{H}=$ Harvest Time, $\mathrm{TChlC}=$ Total Chlorophyll Content, TCC $=$ Total Carbohydrate Content, TPrC $=$ Total Protein Content, TLiC=Total Lipid Content, TPC=Total Phenolic Content, and TFC $=$ Total Flavonoid Content.

Interaction among $\mathrm{N}, \mathrm{K}$ and $\mathrm{ER}$ have shown discrete effects on growth, physiology, and phytochemical content with $\mathrm{N} 0 \mathrm{~K} 30>\mathrm{N} 90 \mathrm{~K} 0$ and ER $75>50>100>25 \%$ treatment (Tables 1, 2 and $3)$. The highest and lowest yields of plant biomass and metabolite content were observed under N0K30(70) and N90K0(25), respectively (Figures 1, 10 and 13). The results showed that the interaction of $\mathrm{N}, \mathrm{K}$ and $\mathrm{ER}$ are highly significant $(\mathrm{p} \leq 0.0001)$ in Cond, CNB, TChlC, TPrC and TFC analysis, $(\mathrm{p} \leq 0.05)$ in NoL, CF and PWP, and not significant in TLA, Photo, TCC, TLiC and TPC (Tables 2 and 3). The 75\% ER was significantly affected plant biomass as well as phytochemical content, possibly due to altered metabolic homeostasis affected by $\mathrm{N}, \mathrm{K}$ and water supply (Figure 1) (Le Bot et al., 2009). As ER decreased from 100 to $25 \%$, the Photo, Cond and CF were also reduced (Figures 2, 3 and 4). Meanwhile, the phytochemical content has exhibited significant negative relationship with PWP, indicating that increased thermal and $\mathrm{pH}$ stress in plants under low water supply has increased the secondary metabolites content such as phenolic compound (Figure 10) (Fonseca et al., 2006).
In growth analysis, TPDW, NoL and TLA, the treatment interaction was statistically not significant $(\mathrm{p} \leq 0.05)$, but significantly different $(\mathrm{p} \leq 0.05)$ in harvesting time (Table 2). In physiological analysis, Cond, TChlC, CF and PWP, the treatment interaction was statistically significant $(\mathrm{p} \leq 0.05)$, and in harvesting time (Table 2). However, in Photo, the treatment interaction was statistically not significant $(p \leq 0.05)$, but, significantly different $(\mathrm{p} \leq 0.05)$ in harvesting time (Table 2). In phytochemical analysis, TCC, TPrC and TLiC, the treatment interaction was statistically significant $(\mathrm{p} \leq 0.05)$, and in harvesting time (Table 3). Meanwhile, in TPC, the treatment interaction was statistically not significant $(\mathrm{p} \leq 0.05)$, but significantly different $(\mathrm{p} \leq 0.05)$ in harvesting time (Table 3). In TFC, the treatment interaction was statistically significant $(\mathrm{p} \leq 0.05)$, and in harvesting time (Table 3).

The study has shown no significant difference in Photo which has caused NoL, TLA and subsequently TPDW to be significantly affected (Table 1). Meanwhile, Cond, TChlC and CF have relatively affected TCC, TPrC, TLiC and TFC (Table 1). The event was probably because of the source (Photo) and sink (metabolites) attributes during the plant growth were negatively interacted 
according to growth-differentiation balance hypothesis in the study (Le Bot et al., 2009). The trade-off between primary (growth) and secondary products (defence/stress tolerance) has emerged from developmental constraints in growing plant cells, and direct competition for resources between primary and secondary metabolism (Caretto et al., 2015; Le Bot et al., 2009). Therefore, when moderate resource limitation constrains the plant growth rate greater than the net assimilation rate, photosynthate will accumulates in the tissues and support the secondary metabolic processes, and resulted in increases of constitutive secondary metabolites in the tissues (Jimenez-Garcia et al., 2013; Ncube \& Van Staden, 2015; Shitan, 2016). These variations may be due to inherent physiological abilities of the treated plants to absorb and utilise the given fertilizers and water rates in relation to the requirements for growth and development (Selmar \& Kleinwächter, 2013).

The plants' water use efficiency study showed that the optimum ER rate for effective production of carbohydrate, protein, lipid and flavonoid was 25 to $75 \%$, irrigating for every two days, and the plants was supply with low $\mathrm{N}$ rate (Figures 7, 8, 9 and 13). Meanwhile, caffeic acid and kaempferol, which are the major phenolic and flavonoid component in $G$. procumbens were elucidated as marker compounds for plants' quality control (Figures 11, 12, 14 and 15) (Iqbal et al., 2017; Li et al., 2017; Mou \& Dash, 2016; Tan et al., 2016; Xu et al., 2015). In this study, the plants acquired no additional amounts of $\mathrm{N}$ (N90) or K (K30) in alleviating the adverse effects of water stress on plant growth when ER treatment was not significant in TPDW, NoL and TLA (Tables 1 and 2). However, the treatments were affecting primary metabolites and flavonoid content (Tables 1 and 3), respectively.

Meanwhile, Photo was not significant $(\mathrm{p} \leq 0.05)$ in relation to all interaction treatments, which probably determined the overall yield (Table 4). The Photo is related to carbon assimilation, dry matter production and TChlC, and Cond are the major factors determining the Photo (Hill et al., 2011). In this study, the increased Cond due to K has increased the plant's drought resistance through its functions in stomatal regulation. The Cond was highest under 75 (\% ER) in N0K30 treatment compared to 100
$(\%$ ER) in N90K0 (Figure 3) (Selmar \& Kleinwächter, 2013). In addition, $K$ also important in controlling the Cond because the concentration gradient of $\mathrm{K}$ between internal and external of stomatal guard cells has affected the solute potential of the plant cells (Chen et al., 2013). As mentioned before, under water deficit condition, the net Photo has decreased significantly (Jaafar et al., 2012). Under this condition, the Photo was limited due to low $\mathrm{CO}_{2}$ availability because of reduced stomatal and mesophyll conductance. Limited $\mathrm{CO}_{2}$ assimilation has resulted in increased allocation of photoassimilates to secondary metabolite production (Ibrahim \& Jaafar, 2012; Ren et al., 2014; Zheng, 2009). The increased secondary metabolite production under low Photo was due to increases in shikimic acid pathway activity under stressed conditions, especially under water deficit. This suggests that the up-regulation of shikimic acid pathway involved in secondary metabolites production is under down-regulated photosynthesis (Dewick, 2002; Herrmann, 1995).

One of the objectives in this study was to examine the effects of ER interaction treatment with $\mathrm{N}$ and $\mathrm{K}$ on growth and phytochemical content quality. Indeed, water stress was significantly important abiotic stress factor affecting growth and phytochemical properties as shown in the results (Espírito-santo et al., 1999; Galieni et al., 2015; Mohd Zain et al., 2014b). Usually, limited availability of water has negative effects on plant growth and development (Khalid, 2006). However, non-severe water deficit has been shown beneficial to the accumulation of secondary metabolite compounds as recorded in this study, where $75 \%$ ER has significantly produced high plant biomass as well as primary and secondary metabolites content accordingly (Figures 1, 10 and 13) (Marchese et al., 2010). Under high water stress, there was a limitation of carbon translocation to sinks. Therefore, the carbon was accumulated as carbohydrates, which leads to increases in carbon pool and subsequently allocated for secondary metabolism in the plant (Abrahamson et al., 1988; Hill et al., 2011; Zheng, 2009). However, the result has shown less significance $(\mathrm{p} \leq 0.05)$ in TCC in relation to ER treatment and in harvest time (Figure 7).

The results suggested that water stress has enhanced the secondary metabolite content 
(Kleinwächter \& Selmar, 2014; Marchese et al., 2010). However, the increases of metabolites content in stress-related plants does not prove the rate of metabolites synthesis in plants has increased, since the water stress treatment has reduced the growth and biomass production (Murthy et al., 2014). Nevertheless, plants suffering from water stress, in principle, will synthesize and accumulate the same amounts of metabolites similar to well-watered plants, but due to the reduction in plant biomass, product concentration on fresh or dry weight basis was enhanced (Le Bot et al., 2009; Ncube \& Van Staden, 2015). On top of that, even though the stressed plants were small, however, the secondary metabolites content (phenolic) was increase $(87.5 \%)$ compared to previous reported study (Figure 10). The event was probably because of plant resource allocation for growth which influenced the phenolic content in plant tissue was affected by carbon nutrient balance. In favourable conditions, plants will allocate carbon for growth, however, in low nutrients and water, the carbon will be accumulated and used for secondary metabolites synthesis (Abrahamson et al., 1988; Massad et al., 2011; Soubeyrand et al., 2014; Zheng, 2009).

\section{CONCLUSION}

Low rate of $\mathrm{N}$ with moderate level of $\mathrm{K}$ and $75 \%$ ER have affected plant biomass and phytochemical content. Meanwhile, caffeic acid and kaempferol were detected as marker compounds in $G$. procumbens. In addition, the study (protected environment cultivation) has shown higher phytochemical content production, TPC (150 to $300 \mathrm{mg} \mathrm{CAE} / \mathrm{g} \mathrm{DW}$ ) compared to open field cultivation ( 0.017 to $200 \mathrm{mg} \mathrm{CAE} / \mathrm{g}$ DW) which were reported in other study. Further field study on the magnitude of light, water and fertilization interaction effect should be conducted to establish new means for managing G. procumbens plant growth and phytochemical content quality significantly.

\section{ACKNOWLEDGMENTS}

The authors would like to thank Ministry of Higher Education Malaysia and Universiti Malaysia Sarawak for the financial support, and Plant Physiology Laboratory, Universiti Putra Malaysia and Plant Biotechnology Research Laboratory, Universiti Malaya for the research facilities assistance.

\section{REFERENCES}

Abrahamson, W. G., Anderson, S. S., \& McCrea, K. D. 1988. Effects of manipulation of plant carbon nutrient balance on ball resistance to a gallmaking herbivore. Oecologia 77(3): 302-306.

Akowuah, G. A., Mariam, A., \& Chin, J. H. 2009. The effect of extraction temperature on total phenols and antioxidant activity of Gynura procumbens leaf. Research Article 5: 81-85.

Altemimi, A., Lakhssassi, N., Baharlouei, A., Watson, D., \& Lightfoot, D. 2017. Phytochemicals: Extraction, isolation, and identification of bioactive compounds from plant extracts. Plants 6(42): 1-23.

An, H., \& Shangguan, Z. P. 2008. Specific leaf area, leaf nitrogen content, and photosynthetic acclimation of Trifolium repens L. seedlings grown at different irradiances and nitrogen concentrations. Photosynthetica 46(1): 143-147.

Armengaud, P., Sulpice, R., Miller, A. J., Stitt, M., Amtmann, A., \& Gibon, Y. 2009. Multilevel analysis of primary metabolism provides new insights into the role of potassium nutrition for glycolysis and nitrogen assimilation in arabidopsis roots. Plant Physiology 150(2): 772-785.

Armstrong, D. L. 1998. Better Crops with Plant Food. Georgia: Potash \& Phosphate Institute.

Ashokkumar, K., Selvaraj, K., \& Saradha Devi, K. M. 2013. Reverse phase-high performance liquid chromatographydiode array detector (RP-HPLC-DAD) analysis of flavonoids profile from curry leaf (Murraya koenigii L.). Journal of Medicinal Plants Research 7(47): 3393-3399.

Awang, Y., Shaharom, A. S., Mohamad, R. B., \& Selamat, A. 2009. Chemical and physical characteristics of cocopeat-based media mixtures and their effects on the growth and development of Celosia cristata. American Journal of Agricultural and Biological Science 4(1): 63-71.

Bellés, J. M., Garro, R., Pallás, V., Fayos, J., Rodrigo, I., \& Conejero, V. 2006. Accumulation of gentisic acid as associated with systemic infections but not with the hypersensitive response in plant-pathogen interactions. Planta 223: 500-511.

Caretto, S., Linsalata, V., Colella, G., Mita, G., \& Lattanzio, V. 2015. Carbon fluxes between primary metabolism and phenolic pathway in plant tissues under stress. International Journal of Molecular Sciences 16: 26378-26394.

Chan, L. K., Keng, C. L., Yee, L. S., \& Pin, P. L. 2009. Micropropagation of Gynura procumbens ( Lour.) Merr. an important medicinal plant. Journal of Medicinal Plants Research 3(3): 105-111.

Chen, Y., Yu, M., Zhu, Z., Zhang, L., \& Guo, Q. 2013. Optimisation of potassium chloride nutrition for proper growth, physiological development and bioactive 
component production in Prunella vulgaris L. PLOS ONE $8(7): 1-7$.

Cheng, X., Liu, J., Shu, J., \& Yu, M. K. 2014. Effects of different light intensity on the growth and nutrients content of Gynura. Advanced Materials Research 955-959: 3766-3769.

Cheynier, V., Comte, G., Davies, K. M., Lattanzio, V., \& Martens, S. 2013. Plant phenolics: Recent advances on their biosynthesis, genetics, and ecophysiology. Plant Physiology and Biochemistry 72: 1-20.

Davies, M. J., Atkinson, C. J., Burns, C., Woolley, J. G., Hipps, N. A., Arroo, R. R. J., Dungey, N., Robinson, T., Brown, P., Flockart, I., Hill, C., Smith, L. \& Bentley, S. 2009. Enhancement of artemisinin concentration and yield in response to optimization of nitrogen and potassium supply to Artemisia annua. Annals of Botany 104: 315-323.

de Matos Nunes, J., Bertodo, L. O. O., da Rosa, L. M. G., Von Poser, G. L., \& Rech, S. B. 2014. Stress induction of valuable secondary metabolites in Hypericum polyanthemum acclimatized plants. South African Journal of Botany 94: 182189.

Dewick, P. M. 2002. The Shikimate Pathway: Aromatic Amino Acids and Phenylpropanoids. London: John Wiley \& Sons.

Dunford, N. T., \& Vazquez, R. S. 2005. Effect of water stress on plant growth and thymol and carvacrol concentrations in Mexican oregano grown under controlled conditions. Journal of Applied Horticulture 7(1): 20-22.

Espírito-santo, M. M., Fernandes, G. W., Allain, L. R., \& Reis, T. R. F. 1999. Tannins in Baccharis dracunculifolia (Asteraceae): Effects of seasonality, water aavailability and plant sex. Acta Botanica Brasilica 13(2): 167-174.

Figueiredo, A. C., Barroso, J. G., Pedro, L. G., \& Scheffer, J. J. C. 2008. Factors affecting secondary metabolite production in plants: volatile components and essential oils. Flavour and Fragrance Journal 23: 213-226.

Filipović, A., Poljak, M., \& Škobić, D. 2013. Response of chlorophyll a, SPAD values and chlorophyll fluorescence parameters in leaves of apricot affected some abiotic factors. Journal of Food Science and Engineering 3: 19-24.

Fonseca, J. M., Rushing, J. W., Rajapakse, N. C., Thomas, R. L., \& Riley, M. B. 2006. Potential implications of medicinal plant production in controlled environments: the case of feverfew (Tanacetum parthenium). HortScience 41(3): 531-535.

Galieni, A., Di Mattia, C., De Gregorio, M., Speca, S., Mastrocola, D., Pisante, M., \& Stagnari, F. 2015. Effects of nutrient deficiency and abiotic environmental stresses on yield, phenolic compounds and antiradical activity in lettuce (Lactuca sativa L.). Scientia Horticulturae 187: 93-101.

Giedyk, M. 2011. HPLC as an analytical and preparative method. Warsaw: Polish Academy of Science.

Hansen, J., \& Moller, I. B. 1975. Analysis of starch and soluble sugars with Anthrone reagent. Anal Biochemistry 68: 87-94.

Herrmann, K. M. 1995. The shikimate pathway: Early steps in the biosynthesis of aromatic compounds. The Plant Cell 7(7): 907-919.

Hill, J. P., Germino, M. J., \& Alongi, D. A. 2011. Carbon-use efficiency in green sinks is increased when a blend of apoplastic fructose and glucose is available for uptake. Journal of Experimental Botany 62(6): 1-10.

Houle, G., Morel, L., Reynolds, C. E., \& Siegel, J. 2001. The effect of salinity on different developmental stages of an endemic annual plant, Aster laurentianus (Asteraceae). American Journal of Botany 88(1): 62-67.

Ibrahim, M. H., Ismail, A., Omar, H., Mohd Nadzir, M. N. H., \& Mohd Zain, N. A. 2017. Primary, secondary metabolites, biochemical and antioxidant activity of Orthosiphon staminues Benth (Misai Kucing) under cadmium exposure. Annual Research \& Review in Biology 19(1): 1-14.

Ibrahim, M. H., Ismail, A., Omar, H., \& Zain, N. A. M. 2017.
Application effects of cadmium and humic acid on the growth, chlorophyll fluorescence, leaf gas exchange and secondary metabolites in Misai Kucing (Orthosiphon stamineus) Benth. Annual Research \& Review in Biology 18(3): $1-14$.

Ibrahim, M. H., \& Jaafar, H. Z. E. 2012. Impact of elevated carbon dioxide on primary, secondary metabolites and antioxidant responses of Eleais guineensis Jacq. (oil palm) seedlings. Molecules 17: 5195-5211.

Ibrahim, M. H., Jaafar, H. Z. E., Karimi, E., \& Ghasemzadeh, A. 2012. Primary, secondary metabolites, photosynthetic capacity and antioxidant activity of the malaysian herb Kacip Fatimah (Labisia Pumila Benth) exposed to potassium fertilization under greenhouse conditions. International Journal of Molecular Sciences 13: 15321-15342.

Ibrahim, M. H., Jaafar, H. Z. E., Karimi, E., \& Ghasemzadeh, A. 2013. Impact of organic and inorganic fertilizers application on the phytochemical and antioxidant activity of Kacip Fatimah (Labisia pumila Benth). Molecules 18: 10973-10988.

Ibrahim, M. H., Jaafar, H. Z. E., Karimi, E., \& Ghasemzadeh, A. 2014. Allocation of secondary metabolites, photosynthetic capacity, and antioxidant activity of Kacip Fatimah (Labisia pumila Benth) in response to CO2 and light intensity. The Scientific World Journal 2014: 1-13.

Ibrahim, M. H., Jaafar, H. Z. E., Rahmat, A., \& Rahman, Z. A. 2011. Effects of nitrogen fertilization on synthesis of primary and secondary metabolites in three varieties of Kacip Fatimah (Labisia pumila Blume). International Journal of Molecular Sciences 12: 5238-5254.

Iqbal, Z., Bello, I., Asmawi, M. Z., Al-Mansoub, M. A., Ahmad, A., Jabeen, Q., \& Fei, Y. M. 2017. Vasorelaxant activities and the underlying pharmacological mechanisms of Gynura procumbens Merr. leaf extracts on rat thoracic aorta. Inflammopharmacology 2017: 1-11.

Iskander, M. N., Song, Y., Coupar, I. M., \& Jiratchariyakul, W. 2002. Antiinflammatory screening of the medicinal plant Gynura procumbens. Plant Foods for Human Nutrition 57: 233 244.

Ismail, N. A., Kamariah, A. S., Lim, L. B. L., \& Ahmad, N. 2015. Phytochemical and pharmacological evaluation of methanolic extracts of the leaves of Nepenthes bicalcarata Hook. F. International Journal of Pharmacognosy and Phytochemical Research 7(6): 1127-1138.

Ismail, N.Z., Arsad, H., Samian, M. R., \& Hamdan, M. R. 2017. Determination of phenolic and flavonoid contents, antioxidant activities and GC-MS analysis of Clinacanthus nutans (Acanthaceae) in different locations. AGRIVITA Journal of Agricultural Science 39(3): 335-344.

Jaafar, H. Z. E., Ibrahim, M. H., \& Fakri, N. F. M. 2012. Impact of soil field water capacity on secondary metabolites, phenylalanine ammonia-lyase (PAL), maliondialdehyde (MDA) and photosynthetic responses of malaysian Kacip Fatimah (Labisia pumila Benth). Molecules 17(6): 7305-7322.

Jamaludin, D., Abd Aziz, S., Ahmad, D., \& Jaafar, H. Z. E. 2015. Impedance analysis of Labisia pumila plant water status. Information Processing in Agriculture 2: 161-168.

Jimenez-Garcia, S. N., Vazquez-Cruz, M. A., Guevara-Gonzalez, R. G., Torres-Pacheco, I., Cruz-Hernandez, A., \& Feregrino-Perez, A. A. 2013. Current approaches for enhanced expression of secondary metabolites as bioactive compounds in plants for agronomic and human health purposes - A review. Polish Journal of Food and Nutrition Sciences 63(2): 67-78.

John, E. C. 1995. Assays for Total Protein. London: John Wiley \& Sons.

Kaewseejan, N., \& Siriamornpun, S. 2015. Bioactive components and properties of ethanolic extract and its fractions from Gynura procumbens leaves. Industrial Crops and Products 74: 
271-278.

Kaewseejan, N., Sutthikhum, V., \& Siriamornpun, S. 2015. Potential of Gynura procumbens leaves as source of flavonoidenriched fractions with enhanced antioxidant capacity. Journal of Functional Foods 12: 120-128.

Kaiser, D. E., Rosen, C. J., \& Lamb, J. A. 2016. Potassium for Crop Production. Minnesota: University of Minnesota Extension.

Kennelly, M., O’Mara, J., Rivard, C., Miller, G. L., \& Smith, D. 2012. Introduction to abiotic disorders in plants. The Plant Health Instructor 2012: 1-31.

Khalid, K. A. 2006. Influence of water stress on growth, essential oil, and chemical composition of herbs (Ocimum sp.). International Agrophysics 20: 289-296.

Kleczewski, N. M., Herms, D. A., \& Bonello, P. 2010. Effects of soil type, fertilization and drought on carbon allocation to root growth and partitioning between secondary metabolism and ectomycorrhizae of Betula papyrifera. Tree Physiology 30: 807-817.

Kleinwächter, M., \& Selmar, D. 2014. New insights explain that drought stress enhances the quality of spice and medicinal plants: potential applications. Agronomy for Sustainable Development 35: 121-131.

Krishnan, V., Ahmad, S., \& Mahmood, M. 2015. Antioxidant potential in different parts and callus of Gynura procumbens and different parts of Gynura bicolor. BioMed Research International 2015: 1-7.

Larbat, R., Olsen, K. M., Slimestad, R., Løvdal, T., Bénard, C., Verheul, M., Bourgaud, F., Robin, C. \& Lillo, C. 2012. Influence of repeated short-term nitrogen limitations on leaf phenolics metabolism in tomato. Phytochemistry 77: 119_ 128.

Le Bot, J., Bénard, C., Robin, C., Bourgaud, F., \& Adamowicz, S. 2009. The trade-off between synthesis of primary and secondary compounds in young tomato leaves is altered by nitrate nutrition: Experimental evidence and model consistency. Journal of Experimental Botany 60(15): 43014314.

Li, F., Gao, J., Xue, F., Yu, X., \& Shao, T. 2016. Extraction optimization, purification and physicochemical properties of polysaccharides from Gynura medica. Molecules 21: 1-13.

Li, J. E., Wang, W. J., Zheng, G. D., \& Li, L. Y. 2017. Physicochemical properties and antioxidant activities of polysaccharides from Gynura procumbens leaves by fractional precipitation. International Journal of Biological Macromolecules 95: 719-724.

Li, Z. 2002. Effects of Several Abiotic and Biotic Factors and Plant Hormones on Growth, Morphology, and Camptothecin Accumulation in Camptotheca acuminata Seedlings. (Unpublished doctoral thesis), Louisiana State University and Agricultural and Mechanical College, Lousiana.

Loh, F. C. W., Grabosky, J. C., \& Bassuk, N. L. 2002. Using the SPAD 502 meter to assess chlorophyll and nitrogen content of Benjamin Fig and cottonwood leaves. Hort Technology 12(4): 682-686.

Lowry, O. H., Rosebrough, N. J., Farr, A. L., \& Randall, R. J. 1951. Protein measurement with the folin phenol reagent. Journal of Biological Chemistry 193(1): 265-275.

Lowry, O. H., Rosebrough, N. J., Farr, A. L., \& Randall, R. J. (2000). Total protein estimation by Lowry's method. Maine: Maine College of Art.

Marchese, J. A., Ferreira, J. F. S., Rehder, V. L. G., \& Rodrigues, O. 2010. Water deficit effect on the accumulation of biomass and artemisinin in annual wormwood (Artemisia annua L., Asteraceae). Brazilian Journal of Plant Physiology 22(1): 1-9.

Massad, T. J., Fincher, R. M., Smilanich, A. M., \& Dyer, L. 2011. A quantitative evaluation of major plant defense hypotheses, nature versus nurture, and chemistry versus ants. Artbropod-Plant Interactions 5(2): 125-139.

Michalak, A. (2006). Phenolic compounds and their antioxidant activity in plants growing under heavy metal stress. Polish Journal of Environmental Study 15(4): 523-530.

Mikkelsen, R. 2008. Managing potassium for crop production. Better Crops with Plant Food 92(2): 26-29.

Mohd Zain, N. A., \& Ismail, M. R. 2016. Effects of potassium rates and types on growth, leaf gas exchange and biochemical changes in rice (Oryza sativa) planted under cyclic water stress. Agricultural Water Management 164: 83-90.

Mohd Zain, N. A., Ismail, M. R., Mahmood, M., Puteh, A., \& Ibrahim, M. H. 2014. Alleviation of water stress effects on MR220 rice by application of periodical water stress and potassium fertilization. Molecules 19: 1795-1819.

Mohd Zain, N. A., Ismail, M. R., Puteh, A., Mahmood, M., \& Islam, M. R. 2014a. Drought tolerance and ion accumulation of rice following application of additional potassium fertilizer. Communications in Soil Science and Plant Analysis 45: 2502-2514.

Mohd Zain, N. A., Ismail, M. R., Puteh, A., Mahmood, M., \& Islam, M. R. 2014b. Impact of cyclic water stress on growth, physiological responses and yield of rice (Oryza sativa L.) grown in tropical environment. Ciência Rural 44(12): 21362141.

Mongkhonsin, B., Nakbanpote, W., Hokura, A., Nuengchamnong, N., \& Maneechai, S. 2016. Phenolic compounds responding to zinc and/or cadmium treatments in Gynura pseudocbina (L.) DC. extracts and biomass. Plant Physiology and Biochemistry 109: 549-560.

Morat, N. M. 2013. Total Phenolic and Flavonoid Content of Three Species of Gynura (Unpublished master thesis), Universiti Teknologi MARA, Selangor.

Mou, K. M., \& Dash, P. R. 2016. A comprehensive review on Gynura procumbens leaves. International Journal of Pharmacognosy 3(4): 167-174.

Mráz, P., Tarbush, E., \& Müller-Schärer, H. 2014. Drought tolerance and plasticity in the invasive knapweed Centaurea stoebe s.l. (Asteraceae): Effect of populations stronger than those of cytotype and range. Annals of Botany 114(2): 1-11.

Murchie, E. H., \& Lawson, T. 2013. Chlorophyll fluorescence analysis: A guide to good practice and understanding some new applications. Journal of Experimental Botany 64(13): 3983 3998.

Murthy, H. N., Lee, E. J., \& Paek, K. Y. 2014. Production of secondary metabolites from cell and organ cultures: Strategies and approaches for biomass improvement and metabolite accumulation. Plant Cell, Tissue and Organ Culture 118: 1-16.

Ncube, B., \& Van Staden, J. 2015. Tilting plant metabolism for improved metabolite biosynthesis and enhanced human benefit. Molecules 20: 12698-12731.

Netala, V. R., Ghosh, S. B., Bobbu, P., Anitha, D., \& Tartte, V. 2015. Triterpenoid saponins: A review on biosynthesis, applications and mechanism of their action. International Journal of Pharmacy and Pharmaceutical Sciences 7(1): 24-28.

Ng, H. K., Poh, T. F., Lam, S. K., \& Hoe, S. Z. 2013. Potassium channel openers and prostacyclin play a crucial role in mediating the vasorelaxant activity of Gynura procumbens. BMC Complementary and Alternative Medicine 13(188): 1-11.

Noviyanti, R., Kurnia Sari, R. L., Kristanti, A. N., Yachya, A., \& Manuhara, Y. S. W. 2017. Biomass and flavonoid production of Gynura procumbens (Lour.) Merr. axillary shoots culture induced by sucrose and erythrose 4phosphate. Scholars Academic Journal of Biosciences 14(4): 257 263.

Olkowski, A. A., Amarowicz, R., Peiquiang, Y., Mckinnon, J. J., \& Maenz, D. D. 2003. A rapid HPLC method for 
determination of major phenolic acids in plant material. Polish Journal of Food and Nutrition Sciences 12(1): 53-57.

Olszewska, M. 2007. Quantitative HPLC analysis of flavonoids and chlorogenic acid in the leaves and inflorescences of Prunus serotina EHRH. Acta Chromatographica 19: 253-269.

Oyedeji, S., Animasaun, D. A., Bello, A. A., \& Agboola, O. O. 2014. Effect of NPK and poultry manure on growth, yield, and proximate composition of three amaranths. Journal of Botany 2014: 1-6.

Ozdal, T., Capanoglu, E., \& Altay, F. 2013. A review on proteinphenolic interactions and associated changes. Food Research International 51: 954-970.

Pal, P. K., Kumar, R., Guleria, V., Mahajan, M., Prasad, R., Pathania, V., Gill, B. S., Singh, D., Chand, G., Singh, B., Singh, R. D., \& Ahuja, P. S. 2015. Crop-ecology and nutritional variability influence growth and secondary metabolites of Stevia rebaudiana Bertoni. BMC Plant Biology 15(67): 1-16.

Pallez, L. C., \& Dole, J. M. 2001. Maintaining vegetative potted purple velvet plants. HortTechnology 11(4): 590-595.

Pant, B. D., Pant, P., Erban, A., Huhman, D., Kopka, J., \& Scheible, W. R. 2015. Identification of primary and secondary metabolites with phosphorus status-dependent abundance in Arabidopsis, and of the transcription factor PHR1 as a major regulator of metabolic changes during phosphorus limitation. Plant, Cell \& Environment 38: 172187.

Patra, B., Schluttenhofer, C., Wu, Y., Pattanaik, S., \& Yuan, L. 2013. Transcriptional regulation of secondary metabolite biosynthesis in plants. Biocbimica et Biophysica Acta 1829(11): 1236-1247.

Peterson, R. B., \& Zelitch, I. 1982. Relationship between net CO2 assimilation and dry weight accumulation in field-grown tobacco. Plant Physiology 70: 677-685.

Rahimi, A., Sayadi, F., Dashti, H., \& Tajabadi, A. 2013. Effects of water and nitrogen supply on growth, water-use efficiency and mucilage yield of isabgol (Plantago ovata Forsk). Journal of Soil Science and Plant Nutrition 13(2): 341-354.

Ramakrishna, A., \& Ravishankar, G. A. 2011. Influence of abiotic stress signals on secondary metabolites in plants. Plant Signaling and Behavior 6(11): 1720-1731.

Ramawat, K. G., Dass, S., \& Mathur, M. 2009. The Chemical Diversity of Bioactive Molecules and Therapeutic Potential of Medicinal Plant. Berlin: Springer-Verlag.

Ren, J., Guo, S., Xu, C., Yang, C., Ai, W., Tang, Y., \& Qin, L. 2014. Effects of different carbon dioxide and LED lighting levels on the anti-oxidative capabilities of Gynura bicolor DC. Advances in Space Research 53: 353-361.

Rivai, H., Nurdin, H., Suyani, H., \& Bakhtiar, A. 2011. Karakterisasi ekstrak daun dewa [Gynura pseudocbina (L.) DC] dengan kromatografi cair kinerja tinggi. Jurnal Farmasi Indonesia 5(3): 134-141.

Romagni, J. G. 2009. Biosynthesis of Chemical Signals-de novo Synthesis and Secondary Metabolites. Oxford: EOLSS.

Rosidah, Yam, M. F., Sadikun, A., \& Asmawi, M. Z. 2008. Antioxidant potential of Gynura procumbens. Pharmaceutical Biology 46(9): 616-625.

Said-Al Ahl, H. A. H., \& Hussein, M. S. 2010. Effect of water stress and potassium humate on the productivity of oregano plant using saline and fresh water irrigation. Ozean Journal of Applied Sciences 3(1): 125-141.

Sasidharan, S., Chen, Y., Saravanan, D., Sundram, K. M., \& Latha, L. Y. 2011. Extraction, isolation and characterization of bioactive compounds from plants extracts. African Journal of Traditional Complementary \& Alternative Medicine 8(1): 1-10.

Sasikala, A., Linga Rao, M., \& Savithramma, N. 2013. Quantification of primary and secondary metabolites from leaves and stem bark of Cocblospermum religiosum (L) Alston.
International Research Journal of Pharmacy 4(8): 228-231.

Schuppler, U., He, P. H., John, P. C. L., \& Munns, R. 1998. Effect of water stress on cell division and cdc2-like cell cycle kinase activity in wheat leaves. Plant Physiology 117: 667-678.

Schutzki, R. E., \& Cregg, B. 2007. Abiotic Plant Disorders Symptoms, Signs and Solutions A Diagnostic Guide to Problem Solving. Michigan: Michigan State University Extension.

Selmar, D., \& Kleinwächter, M. 2013. Stress enhances the synthesis of secondary plant products: The impact of stressrelated over-reduction on the accumulation of natural products. Plant and Cell Physiology 54(6): 817-826.

Seow, L. J., Beh, H. K., Umar, M. I., Sadikun, A., \& Asmawi, M. Z. 2014. Anti-inflammatory and antioxidant activities of the methanol extract of Gynura segetum leaf. International Immunopharmacology 23: 186-191.

Shams, K. A., Abdel-Azim, N. S., Tawfik, W. A., Hassanein, H. D., Saleh, M. A., \& Hammouda, F. M. 2015. Green extraction techniques: Effect of extraction method on lipid contents of three medicinal plants of Apiaceae. Journal of Chemical and Pharmacentical Research 7(4): 1080-1088.

Shao, L., Fu, Y., Liu, H., \& Liu, H. 2015. Changes of the antioxidant capacity in Gynura bicolor DC under different light sources. Scientia Horticulturae 184: 40-45.

Shirazi, O. S., Khan Khattak, M. M. A., Mohd Shukri, N. A., \& Mohd Nur Nasyriq, A. 2014. Determination of total phenolic, flavonoid content and free radical scavenging activities of common herbs and spices. Journal of Pharmacognosy and Phytochemistry 3(3): 104-108.

Shitan, N. 2016. Secondary metabolites in plants: Transport and self-tolerance mechanisms. Bioscience, Biotechnology and Biochemistry 80(7): 1283-1293.

Shoeva, O., Mock, H. P., Kukoeva, T. V., Börner, A., \& Khlestkina, E. K. 2016. Regulation of the flavonoid biosynthesis pathway genes in purple and black grains of Hordeum vulgare. PLOS ONE 11(10): 1-16.

Sim, C. C., Zaharah, A. R., Tan, M. S., \& Goh, K. J. 2015. Rapid determination of leaf chlorophyll concentration, photosynthetic activity and NK concentration of Elaies guineensis via correlated SPAD-502 chlorophyll index. Asian Journal of Agricultural Research 9(3): 132-138.

Smith, M., Wu, Y. J., \& Green, O. 1993. Effect of light and waterstress on photosynthesis and biomass production in Boltonia decurrens (Asteraceae), a threatened species. American Journal of Botany 80(8): 859-864.

Soubeyrand, E., Basteau, C., Hilbert, G., van Leeuwen, C., Delrot, S., \& Gomès, E. 2014. Nitrogen supply affects anthocyanin biosynthetic and regulatory genes in grapevine $\mathrm{cv}$. Cabernet-Sauvignon berries. Phytochemistry 103: 38-49.

Szakiel, A., Paçzkowski, C., \& Henry, M. 2011. Influence of environmental biotic factors on the content of saponins in plants. Phytochemistry Reviews 10: 493-502.

Tamayo, P. R., Weiss, O., \& Sanchez-moreiras, A. M. 2001. Gas Exchange Techniques in Photosynthesis and Respiration Infrared Gas Analyser. Dordrecht: Kluwer Academic Publishers.

Tan, H. L., Chan, K. G., Pusparajah, P., Lee, L. H., \& Goh, B. H. 2016. Gynura procumbens: An overview of the biological activities. Frontiers in Pharmacology 7: 1-14.

Teoh, W. Y., Wahab, N. A., Richardson, J. S. ., \& Sim, K. S. 2016. Evaluation of antioxidant properties, cytotoxicity and acute oral toxicity of Gynura procumbens (Compositae). Sains Malaysiana 45(2): 229-235.

Treder, J. 2008. The effects of cocopeat and fertilization on the growth and flowering of oriental lily Star Gazer. Journal of Fruit and Ornamental Plant Research 16: 361-370.

Wang, M., Fu, Y., \& Liu, H. 2015. Nutritional status and ion uptake response of Gynura bicolor DC. between porous-tube and 
traditional hydroponic growth systems. Acta Astronautica 113: 13-21.

Wang, M., Liu, H., Dong, C., Fu, Y., \& Liu, H. 2016. Elevated CO2 enhances photosynthetic efficiency, ion uptake and antioxidant activity of Gynura bicolor DC. grown in a poroustube nutrient delivery system under simulated microgravity. Plant Biology 18: 391-399.

Wu, T., Zhou, X., Deng, Y., Jing, Q., Li, M., \& Yuan, L. 2011. In vitro studies of Gynura divaricata (L.) DC extracts as inhibitors of key enzymes relevant for type 2 diabetes and hypertension. Journal of Ethnopharmacology 136: 305-308.

Xu, B. Q., Yang, P., \& Zhang, Y. Q. 2015. Hypoglycemic activities of lyophilized powder of Gymura divaricata by improving antioxidant potential and insulin signaling in type 2 diabetic mice. Food and Nutrition Research 59: 1-10.

Yadav, R. K., Sangwan, R. S., Sabir, F., Srivastava, A. K., \& Sangwan, N. S. 2014. Effect of prolonged water stress on specialized secondary metabolites, peltate glandular trichomes, and pathway gene expression in Artemisia annua L. Plant Physiology and Biochemistry 74: 70-83.

Yan, F., Yang, X., Liu, C., Huang, S., Liao, L., \& Fu, C. 2014. Extraction optimization of antioxidant polysaccharides from leaves of Gynura bicolor (Roxb. \& Willd.) DC. Food Science and Technology 34(2): 402-407.

Yi, X., Zuo, J., Tan, C., Xian, S., Luo, C., Chen, S., Yu, L., \& Luo, Y. 2016. Kaempferol, a flavonoid compound from Gynura medica induced apoptosis and growth inhibition in MCF-7 breast cancer cell. African Journal of Traditional, Complementary and Alternative Medicines 13(4): 210-215.

Yu, Y., Yang, R., Wan, C., Xu, B., Cao, S., \& Liu, W. 2010. Optimization of total flavonoid compound extraction from Gynura medica leaf using response surface methodology and chemical composition analysis. International Journal of Molecular Sciences 11: 4750-4763.

Zheng, Z. L. 2009. Carbon and nitrogen nutrient balance signaling in plants. Plant Signaling \& Behavior 4(7): 584-591.

Zoratti, L., Karppinen, K., Luengo Escobar, A., Häggman, H., \& Jaakola, L. 2014. Light-controlled flavonoid biosynthesis in fruits. Frontiers in Plant Science 2014: 1-16.

Zulkifle, N. (2006). The study of Gynura procumbens (Lour.) Merr. Crude extract using high performance liquid chromatography (HPLC) (Unpublished master thesis), Universiti Sains Malaysia, Penang. 